\title{
PROMOTIONS AND INCENTIVES IN NONPROFIT AND FOR-PROFIT ORGANIZATIONS
}

\author{
JED DEVARO and DANA BROOKSHIRE*
}

\begin{abstract}
Using data from the 1992-95 Multi-City Study of Urban Inequality, an employer survey, the authors document a new empirical finding that workers are less likely to receive promotions in nonprofit organizations than in for-profit firms. The study also uncovers evidence that wage increases associated with promotion were of comparable magnitudes in the two sectors, as was the potential for within-job wage growth; nonprofits were less likely than for-profits to base promotions on job performance or merit; nonprofits were less likely to use output-contingent incentive contracts to motivate workers; and the observed difference in promotion rates between the nonprofit and for-profit sectors was more pronounced for high-skilled than for low-skilled workers. The authors also propose a theory, based on the idea that nonprofit workers are intrinsically motivated to a greater extent than are for-profit workers, that potentially explains the broad pattern of evidence they uncover.
\end{abstract}

A growing empirical literature on nonprofit organizations has focused heavily on differences in compensation between the nonprofit and for-profit sectors. The premise for much of this work is that compensating differentials might exist between nonprofit and for-profit jobs, with nonprofit workers accepting lower wages in exchange for the opportunity to work toward a meaningful social mission. Differences between nonprofits and for-profits in other (non-wage) aspects of the employment relationship have received much less attention in the literature. This paper

*Jed DeVaro is Assistant Professor of Labor Economics in the School of Industrial and Labor Relations at Cornell University, and Dana Brookshire is an assistant vice president at Bank of America. The authors are grateful for helpful comments from Francine Blau, Ronald Ehrenberg, Martin Farnham, Limor Golan, Jeffrey Groen, Kevin Hallock, Robert Smith, Michael Waldman, and seminar participants at the Society of Labor Economists Annual Meetings, the NBER Summer Institute, and Wesleyan University. They also thank Jason Roche, David Rosenblum and Robert Sullivan for research assistance. is the first to study differences in promotion behavior between the nonprofit and for-profit sectors, using data on promotions from a large cross-section of establishments.

Such an investigation is useful for at least two reasons. First, it sheds light on an important labor market difference between nonprofit and for-profit organizations, apart from the differences in compensation that have been the focus of most prior empirical work. This contributes to a better understanding both of nonprofit organizations and of promotion behavior in firms more generally. Furthermore, since promotions are associated with large wage increases and therefore have implications for wage profiles, the analysis contributes to a deeper

The data used in this study can be downloaded from the ICPSR website. Results that are mentioned but not reported in the paper are available (along with copies of the STATA programs used to generate all results in the paper) from the first author at Cornell University; School of Industrial and Labor Relations; 357 Ives Hall East; Ithaca, NY; 14853; devaro@cornell.edu. 
understanding of the evolution of the wage differentials that have been the main focus of prior work. Second, since much of our discussion focuses on incentive creation, this work contributes to the empirical literature on incentives in organizations.

The issues we address in this paper are important to many, but perhaps to no group more than nonprofit sector workers. Their numbers are large-in 2002, the sector is estimated to have employed some 8.8 million paid workers and enlisted approximately 59 million volunteers for unpaid service (Salamon and Sokolowski 2005; Bureau of Labor Statistics 2002) - and yet by comparison with workers in the private sector, they have received little research attention.

The main objective of this study is to document whether there is any difference in promotion rates between the nonprofit and for-profit sectors, after controlling for the characteristics of workers, firms, and jobs. In addition, we investigate several complementary empirical questions. In particular, we try to determine the extent to which the two sectors differ with respect to the size of wage increases that accompany promotions; the potential for within-job wage growth; the degree to which promotions are based on merit and job performance; the tendency to use output-based incentives as a means for motivating workers; average levels of job performance; the relationship between promotion rates for high-skilled jobs and those for low-skilled jobs; the rate of internal hiring; and turnover rates. After addressing these questions empirically, we propose a theory that potentially explains the broad pattern of evidence we document.

The most likely reason that the question of whether promotion differences exist between the for-profit and nonprofit sector has never been addressed previously is that the necessary data were unavailable. Such an analysis requires data from multiple organizations, including information on nonprofit status, promotion decisions, and detailed characteristics of firms, jobs, and workers. Data sets used in the empirical nonprofit literature generally lack information on promotions. Furthermore, the empirical literature on promotions has used either single-firm data sets (which obviously are not useful for studying promotion differences between nonprofit and for-profit organizations) or cross-sections or panels that span multiple firms but lack information on nonprofit status. Our study is based on data from a large cross-section of establishments that contains the necessary information on promotions, nonprofit status, wages, and detailed worker, firm, and job characteristics. A unique and attractive feature of our data set is that it also contains information on the job-specific performance ratings of workers, an important explanatory variable in models of wages and promotion decisions. Such job-specific performance ratings are rarely available, particularly in data sets spanning multiple firms.

\section{Data: Multi-City Study of Urban Inequality}

The Multi-City Study of Urban Inequality (MCSUI) is a cross-sectional employer survey collected between 1992 and 1995 in the four metropolitan areas of Atlanta, Boston, Detroit, and Los Angeles. The full sample consists of 3,510 establishments. ${ }^{1}$ The survey

\footnotetext{
${ }^{1}$ Harry Holzer conducted the bulk of the survey, producing 3,213 cases. A supplement of 297 cases was provided by Kirschenman, Tilly, and Moss. The survey respondent was the owner in $14.5 \%$ of the cases, the manager or supervisor in $42 \%$, a personnel department official in $31.5 \%$, and someone else in $12 \%$. Screening identified a respondent who actually carried out hiring for the relevant position, and the survey instrument took 30-45 minutes to administer on the telephone, with an overall response rate of $67 \%$. For more information about the data, see Holzer (1996). Slightly less than two-thirds of the cases were drawn from regional employment directories provided by Survey Sampling, Inc. (SSI) based on local telephone directories. This was a sample stratified by establishment size (25\% 1-19 employees, 50\% 20-99 employees, 25\% 100 or more employees) and was designed to be self-weighting. The remaining cases were drawn from the current or most recent employer reported by respondents in a companion household survey. The MCSUI household survey over-sampled low-income areas and areas with high concentrations of racial minorities. The SSI subsample was restricted to employers who had hired a worker for a position that did not require a college degree within the previous three years, whereas the household subsample was not restricted to entry-level jobs in this way. Sampling weights adjust for these considerations, and weighted observations are a representative sample of establishments such as would occur if a random sample of employed people were drawn from each city. We use these sampling weights throughout the study.
} 
Table 1. Occupational Distribution by For-Profit Status.

\begin{tabular}{|c|c|c|c|c|}
\hline \multirow[b]{2}{*}{ Occupation } & \multicolumn{2}{|c|}{ Unweighted Counts } & \multicolumn{2}{|c|}{ Weighted Counts } \\
\hline & Nonprofits & For-Profits & Nonprofits & For-Profits \\
\hline Executive, Administrative, and Managerial Occupations & 48 & 167 & 54.69 & 267.82 \\
\hline Engineers, Surveyors, and Architects & 5 & 40 & 1.66 & 84.76 \\
\hline Natural Scientists and Mathematicians & 4 & 21 & 13.55 & 27.98 \\
\hline Social Scientists, Social Scientists, Religious Workers, Lawyers & 25 & 4 & 34.25 & 3.2 \\
\hline Teachers, Librarians, and Counselors & 75 & 13 & 177.97 & 17.06 \\
\hline Health Diagnosing and Treating Practitioners & 4 & 3 & 1.03 & 2.68 \\
\hline RNs, Pharmacists, Dieticians, Therapists, and Physician's Assts. & 24 & 25 & 48.71 & 52.19 \\
\hline Writers, Artists, Entertainers, and Athletes & 7 & 33 & 5.16 & 33.6 \\
\hline Health Technologists and Technicians & 22 & 31 & 25.97 & 31.44 \\
\hline Technologists and Technicians, except Health & 8 & 65 & 21.36 & 61.06 \\
\hline Marketing and Sales Occupations & 17 & 408 & 16.07 & 395 \\
\hline Administrative Support Occupations, including Clerical & 242 & 677 & 227.43 & 629.35 \\
\hline Service Occupations & 144 & 289 & 111.41 & 208.5 \\
\hline Mechanics and Repairers & 9 & 83 & 4.9 & 70.39 \\
\hline Construction and Extractive Occupations & 3 & 40 & 2.43 & 42.36 \\
\hline Precision Production Occupations & 8 & 101 & 6.99 & 90.79 \\
\hline Production Working Occupations & 5 & 221 & 3.77 & 174.77 \\
\hline Transportation and Material Moving Occupations & 14 & 106 & 7.14 & 90.8 \\
\hline Handlers, Equipment Cleaners, Helpers, and Laborers & 9 & 116 & 5.83 & 93.35 \\
\hline Total & 673 & 2,443 & 770.32 & $2,377.1$ \\
\hline
\end{tabular}

questions pertaining to the establishment's most recently hired worker form the basis for our empirical analysis. Key questions include whether this worker received a promotion by the survey date, whether a promotion was expected within the next five years, and whether the establishment was for-profit. We define all variables in the appendix.

In response to the question about whether the establishment was for-profit, 3,217 respondents answered either "yes" or "no." We code the remaining 293 cases as missing (including responses of "don't know," "no opinion," and "refused"). Henceforth, we refer to establishments with responses of "no" as nonprofits, though these may include some governmental observations. From the 3,217 cases with information on for-profit status, we drop 16 observations for which the reported industry or the most recently hired worker's occupation was agriculture, forestry, or fishing. Of the remaining 3,201 observations, 695 were nonprofits and 2,506 were for-profits.

Missing values reduce the usable sample size for most variables in the survey. For example, in Table 1, which displays the occupational distribution of jobs in our sample by sector, the occupation data are available for only 673 nonprofits and 2,443 for-profits. In multivariate analyses that include many control variables, the analysis sample shrinks considerably. Throughout the paper we report results based on the largest subsample possible for any given specification. However, we have also replicated all tables using a smaller subsample (1,609 establishments, including 288 nonprofits and 1,321 for-profits) that remains fixed across all specifications of the main tables of the paper. This is the largest subsample for which each observation for each variable appearing in any of the tables in the next section is non-missing. In all cases the qualitative results match those we report in the paper, and all of these additional tables are available upon request.

Table 2 displays summary statistics. The fraction of received promotions is only $7.6 \%$ because the sample consists of recently hired workers, many of whom had not been employed with the establishment for long. The unconditional differences in means in the first two rows of Table 2 reveal that received and expected promotions were more likely in for-profits than in nonprofits. The fraction of workers promoted by the survey 
Table 2. Summary Statistics.

\begin{tabular}{|c|c|c|c|c|}
\hline Variable & Full Sample & Nonprofits & For-Profits & $\begin{array}{c}\text { Difference } \\
(p \text {-value })\end{array}$ \\
\hline Promotions & $\begin{array}{c}0.076 \\
(0.006)\end{array}$ & $\begin{array}{c}0.043 \\
(0.009)\end{array}$ & $\begin{array}{c}0.086 \\
(0.007)\end{array}$ & $\begin{array}{c}-0.043 \\
(0.000)\end{array}$ \\
\hline Expected Promotions & $\begin{array}{c}0.666 \\
(0.013)\end{array}$ & $\begin{array}{c}0.560 \\
(0.036)\end{array}$ & $\begin{array}{c}0.694 \\
(0.013)\end{array}$ & $\begin{array}{c}-0.134 \\
(0.000)\end{array}$ \\
\hline \multicolumn{5}{|l|}{ Firm Characteristics } \\
\hline For-Profit Status & $\begin{array}{c}0.752 \\
(0.015)\end{array}$ & & & \\
\hline Franchise & $\begin{array}{c}0.061 \\
(0.006)\end{array}$ & $\begin{array}{c}0.018 \\
(0.006)\end{array}$ & $\begin{array}{c}0.073 \\
(0.007)\end{array}$ & $\begin{array}{c}-0.055 \\
(0.000)\end{array}$ \\
\hline Number of Sites & $\begin{array}{l}62.885 \\
(7.979)\end{array}$ & $\begin{array}{c}37.367 \\
(11.943)\end{array}$ & $\begin{array}{c}73.393 \\
(10.635)\end{array}$ & $\begin{array}{r}-36.026 \\
(0.024)\end{array}$ \\
\hline Establishment Size & $\begin{array}{c}744.814 \\
(225.476)\end{array}$ & $\begin{array}{c}1243.028 \\
(180.76)\end{array}$ & $\begin{array}{c}631.593 \\
(315.958)\end{array}$ & $\begin{array}{r}611.435 \\
\quad(0.093)\end{array}$ \\
\hline Union & $\begin{array}{l}17.569 \\
(1.054)\end{array}$ & $\begin{array}{l}37.506 \\
(3.141)\end{array}$ & $\begin{array}{c}10.982 \\
(0.914)\end{array}$ & $\begin{array}{c}26.523 \\
(0.000)\end{array}$ \\
\hline Fraction of High-Skill Employees & $\begin{array}{c}0.315 \\
(0.012)\end{array}$ & $\begin{array}{c}0.526 \\
(0.022)\end{array}$ & $\begin{array}{c}0.255 \\
(0.013)\end{array}$ & $\begin{array}{c}0.271 \\
(0.000)\end{array}$ \\
\hline Temporary Workers & $\begin{array}{c}0.356 \\
(0.014)\end{array}$ & $\begin{array}{c}0.481 \\
(0.036)\end{array}$ & $\begin{array}{c}0.330 \\
(0.016)\end{array}$ & $\begin{array}{c}0.151 \\
(0.000)\end{array}$ \\
\hline Contract Workers & $\begin{array}{c}0.297 \\
(0.012)\end{array}$ & $\begin{array}{c}0.421 \\
(0.035)\end{array}$ & $\begin{array}{c}0.263 \\
(0.013)\end{array}$ & $\begin{array}{c}0.158 \\
(0.000)\end{array}$ \\
\hline Hiring Rate & $\begin{array}{l}19.548 \\
(1.619)\end{array}$ & $\begin{array}{l}13.734 \\
(4.504)\end{array}$ & $\begin{array}{l}17.018 \\
(1.607)\end{array}$ & $\begin{array}{c}-3.284 \\
(0.492)\end{array}$ \\
\hline Separation Rate & $\begin{array}{l}28.031 \\
(7.424)\end{array}$ & $\begin{array}{l}10.786 \\
(2.571)\end{array}$ & $\begin{array}{l}31.379 \\
(9.733)\end{array}$ & $\begin{array}{r}-20.593 \\
(0.041)\end{array}$ \\
\hline Net Change in Employees & $\begin{array}{c}5.898 \\
(3.087)\end{array}$ & $\begin{array}{l}11.267 \\
(7.527)\end{array}$ & $\begin{array}{c}1.758 \\
(3.438)\end{array}$ & $\begin{array}{c}9.510 \\
(0.251)\end{array}$ \\
\hline \multicolumn{5}{|l|}{ Industry } \\
\hline Construction and Mining & $\begin{array}{c}0.026 \\
(0.004)\end{array}$ & $\begin{array}{c}0.007 \\
(0.003)\end{array}$ & $\begin{array}{c}0.032 \\
(0.005)\end{array}$ & $\begin{array}{c}-0.025 \\
(0.000)\end{array}$ \\
\hline Manufacturing & $\begin{array}{c}0.199 \\
(0.010)\end{array}$ & $\begin{array}{c}0.031 \\
(0.007)\end{array}$ & $\begin{array}{c}0.251 \\
(0.013)\end{array}$ & $\begin{array}{c}-0.220 \\
(0.000)\end{array}$ \\
\hline Transportation & $\begin{array}{c}0.056 \\
(0.007)\end{array}$ & $\begin{array}{c}0.030 \\
(0.012)\end{array}$ & $\begin{array}{c}0.064 \\
(0.010)\end{array}$ & $\begin{array}{c}-0.034 \\
(0.030)\end{array}$ \\
\hline Wholesale Trade & $\begin{array}{c}0.075 \\
(0.010)\end{array}$ & $\begin{array}{c}0.005 \\
(0.002)\end{array}$ & $\begin{array}{c}0.099 \\
(0.014)\end{array}$ & $\begin{array}{c}-0.095 \\
(0.000)\end{array}$ \\
\hline Retail Trade & $\begin{array}{c}0.152 \\
(0.009)\end{array}$ & $\begin{array}{c}0.015 \\
(0.005)\end{array}$ & $\begin{array}{c}0.190 \\
(0.012)\end{array}$ & $\begin{array}{c}-0.175 \\
(0.000)\end{array}$ \\
\hline Finance & $\begin{array}{c}0.073 \\
(0.006)\end{array}$ & $\begin{array}{c}0.030 \\
(0.012)\end{array}$ & $\begin{array}{c}0.084 \\
(0.007)\end{array}$ & $\begin{array}{c}-0.055 \\
(0.000)\end{array}$ \\
\hline Services & $\begin{array}{c}0.401 \\
(0.015)\end{array}$ & $\begin{array}{c}0.829 \\
(0.022)\end{array}$ & $\begin{array}{c}0.275 \\
(0.015)\end{array}$ & $\begin{array}{c}0.554 \\
(0.000)\end{array}$ \\
\hline Public Administration & $\begin{array}{c}0.014 \\
(0.003)\end{array}$ & $\begin{array}{c}0.051 \\
(0.011)\end{array}$ & $\begin{array}{c}0.002 \\
(0.001)\end{array}$ & $\begin{array}{c}0.048 \\
(0.000)\end{array}$ \\
\hline
\end{tabular}

date was twice as high in for-profits as in nonprofits $(8.6 \%$ versus $4.3 \%)$. Similarly, more than $69 \%$ of workers were expected to be promoted in for-profits, versus only $56 \%$ in nonprofits. Both differences in means are statistically significantly different from zero, with t-statistics exceeding 3.5. Table 2 also reveals many other firm and worker 
Table 2. Contin.

\begin{tabular}{|c|c|c|c|c|}
\hline Variable & Full Sample & Nonprofits & For-Profits & $\begin{array}{c}\text { Difference } \\
\text { (p-value })\end{array}$ \\
\hline \multicolumn{5}{|l|}{ Employee Characteristics } \\
\hline Performance & $\begin{array}{l}78.335 \\
(0.428)\end{array}$ & $\begin{array}{c}80.794 \\
(1.259)\end{array}$ & $\begin{array}{l}77.798 \\
(0.465)\end{array}$ & $\begin{array}{c}2.996 \\
(0.026)\end{array}$ \\
\hline Typical Performance & $\begin{array}{l}76.146 \\
(0.389)\end{array}$ & $\begin{array}{l}79.055 \\
(0.728)\end{array}$ & $\begin{array}{l}75.501 \\
(0.479)\end{array}$ & $\begin{array}{c}3.554 \\
(0.000)\end{array}$ \\
\hline High School Degree or More & $\begin{array}{c}0.256 \\
(0.010)\end{array}$ & $\begin{array}{c}0.212 \\
(0.024)\end{array}$ & $\begin{array}{c}0.268 \\
(0.012)\end{array}$ & $\begin{array}{c}-0.056 \\
(0.036)\end{array}$ \\
\hline College Degree or More & $\begin{array}{c}0.348 \\
(0.017)\end{array}$ & $\begin{array}{c}0.556 \\
(0.035)\end{array}$ & $\begin{array}{c}0.303 \\
(0.020)\end{array}$ & $\begin{array}{c}0.254 \\
(0.000)\end{array}$ \\
\hline Tenure & $\begin{array}{r}116.655 \\
(4.877)\end{array}$ & $\begin{array}{r}106.086 \\
(9.354)\end{array}$ & $\begin{array}{r}119.093 \\
(6.057)\end{array}$ & $\begin{array}{r}-13.007 \\
(0.243)\end{array}$ \\
\hline \multicolumn{5}{|l|}{ Demographics } \\
\hline Age & $\begin{array}{l}30.606 \\
(0.249)\end{array}$ & $\begin{array}{l}33.067 \\
(0.745)\end{array}$ & $\begin{array}{l}30.200 \\
(0.246)\end{array}$ & $\begin{array}{c}2.867 \\
(0.000)\end{array}$ \\
\hline Male & $\begin{array}{c}0.477 \\
(0.014)\end{array}$ & $\begin{array}{c}0.314 \\
(0.035)\end{array}$ & $\begin{array}{c}0.534 \\
(0.016)\end{array}$ & $\begin{array}{c}-0.220 \\
(0.000)\end{array}$ \\
\hline White & $\begin{array}{c}0.604 \\
(0.014)\end{array}$ & $\begin{array}{c}0.602 \\
(0.035)\end{array}$ & $\begin{array}{c}0.598 \\
(0.016)\end{array}$ & $\begin{array}{c}0.004 \\
(0.925)\end{array}$ \\
\hline Black & $\begin{array}{c}0.171 \\
(0.009)\end{array}$ & $\begin{array}{c}0.193 \\
(0.024)\end{array}$ & $\begin{array}{c}0.160 \\
(0.010)\end{array}$ & $\begin{array}{c}0.033 \\
(0.196)\end{array}$ \\
\hline Hispanic & $\begin{array}{c}0.144 \\
(0.010)\end{array}$ & $\begin{array}{c}0.138 \\
(0.024)\end{array}$ & $\begin{array}{c}0.153 \\
(0.011)\end{array}$ & $\begin{array}{c}-0.015 \\
(0.566)\end{array}$ \\
\hline Other Non-White & $\begin{array}{c}0.081 \\
(0.010)\end{array}$ & $\begin{array}{c}0.068 \\
(0.017)\end{array}$ & $\begin{array}{c}0.089 \\
(0.013)\end{array}$ & $\begin{array}{c}-0.021 \\
(0.327)\end{array}$ \\
\hline \multicolumn{5}{|l|}{ Job Characteristics } \\
\hline Talk & $\begin{array}{c}0.608 \\
(0.014)\end{array}$ & $\begin{array}{c}0.828 \\
(0.028)\end{array}$ & $\begin{array}{c}0.531 \\
(0.016)\end{array}$ & $\begin{array}{c}0.298 \\
(0.000)\end{array}$ \\
\hline Phone & $\begin{array}{c}0.565 \\
(0.014)\end{array}$ & $\begin{array}{c}0.596 \\
(0.035)\end{array}$ & $\begin{array}{c}0.560 \\
(0.016)\end{array}$ & $\begin{array}{c}0.035 \\
(0.361)\end{array}$ \\
\hline Math & $\begin{array}{c}0.679 \\
(0.013)\end{array}$ & $\begin{array}{c}0.623 \\
(0.034)\end{array}$ & $\begin{array}{c}0.699 \\
(0.014)\end{array}$ & $\begin{array}{c}-0.076 \\
(0.037)\end{array}$ \\
\hline Compute & $\begin{array}{c}0.587 \\
(0.013)\end{array}$ & $\begin{array}{c}0.607 \\
(0.035)\end{array}$ & $\begin{array}{c}0.604 \\
(0.014)\end{array}$ & $\begin{array}{c}0.003 \\
(0.939)\end{array}$ \\
\hline Read & $\begin{array}{c}0.606 \\
(0.013)\end{array}$ & $\begin{array}{c}0.731 \\
(0.033)\end{array}$ & $\begin{array}{c}0.578 \\
(0.015)\end{array}$ & $\begin{array}{c}0.153 \\
(0.000)\end{array}$ \\
\hline Write & $\begin{array}{c}0.421 \\
(0.015)\end{array}$ & $\begin{array}{c}0.620 \\
(0.031)\end{array}$ & $\begin{array}{c}0.369 \\
(0.017)\end{array}$ & $\begin{array}{c}0.251 \\
(0.000)\end{array}$ \\
\hline Position Requires College Degree & $\begin{array}{c}0.283 \\
(0.017)\end{array}$ & $\begin{array}{c}0.518 \\
(0.035)\end{array}$ & $\begin{array}{c}0.226 \\
(0.020)\end{array}$ & $\begin{array}{c}0.291 \\
(0.000)\end{array}$ \\
\hline Number of Observations & 3,201 & 695 & 2,506 & $\mathrm{n} / \mathrm{a}$ \\
\hline
\end{tabular}

Notes: Cell entries are weighted means for the full, nonprofit, and for-profit samples. Numbers in parentheses are standard errors in the first three columns and p-values in the fourth column. Many variables contain missing values, and statistics are computed using all available data for each variable.

characteristics that differ between the forprofit and nonprofit subsamples. Most of these differences in means are statistically significantly different from zero.

\section{Promotions in Nonprofit and For-Profit Organizations}

The results in Table 2 on differences 
Table 3. Probabilities of

Promotion and Expected Promotion.

\begin{tabular}{lcc}
\hline Independent Variable & Promotions & $\begin{array}{c}\text { Expected } \\
\text { Promotions }\end{array}$ \\
\hline For-Profit Status & $0.042^{* *}$ & $0.125^{* *}$ \\
Employee Characteristics & $(0.014)$ & $(0.049)$ \\
Performance & & \\
Typical Performance & $-0.180 * *$ & $0.407 * *$ \\
& $(0.048)$ & $(0.094)$ \\
High School Degree & -0.001 & $-0.324 * *$ \\
or More & $(0.013)$ & $(0.116)$ \\
College Degree or More & $-0.052^{* *}$ & 0.001 \\
& $(0.014)$ & $0.030)$ \\
Tenure & $0.168 * *$ & $-0.040)$ \\
& $(0.033)$ & $(0.091)$
\end{tabular}

Firm Characteristics

\begin{tabular}{|c|c|c|}
\hline Franchise & $\begin{array}{c}0.002 \\
(0.023)\end{array}$ & $\begin{array}{l}-0.000 \\
(0.062)\end{array}$ \\
\hline Number of Sites & $\begin{array}{c}0.003 \\
(0.012)\end{array}$ & $\begin{array}{c}0.079 \\
(0.049)\end{array}$ \\
\hline Establishment Size & $\begin{array}{l}-0.006 \\
(0.006)\end{array}$ & $\begin{array}{l}0.077 * * \\
(0.033)\end{array}$ \\
\hline Union & $\begin{array}{l}-0.043^{* *} \\
(0.020)\end{array}$ & $\begin{array}{l}-0.147 * * \\
(0.057)\end{array}$ \\
\hline $\begin{array}{l}\text { Fraction of High-Skill } \\
\text { Employees }\end{array}$ & $\begin{array}{l}-0.008 \\
(0.025)\end{array}$ & $\begin{array}{l}0.119 * * \\
(0.057)\end{array}$ \\
\hline Temporary Workers & $\begin{array}{l}-0.001 \\
(0.013)\end{array}$ & $\begin{array}{l}0.089 * * \\
(0.033)\end{array}$ \\
\hline Contract Workers & $\begin{array}{c}0.005 \\
(0.014)\end{array}$ & $\begin{array}{l}-0.003 \\
(0.033)\end{array}$ \\
\hline \multicolumn{3}{|l|}{ adustry Controls } \\
\hline Construction and Mining & $\begin{array}{c}0.025 \\
(0.036)\end{array}$ & $\begin{array}{l}0.131 * * \\
(0.058)\end{array}$ \\
\hline Manufacturing & $\begin{array}{l}-0.023 \\
(0.014)\end{array}$ & $\begin{array}{l}0.073^{* *} \\
(0.036)\end{array}$ \\
\hline Transportation & $\begin{array}{l}-0.027 \\
(0.018)\end{array}$ & $\begin{array}{c}0.032 \\
(0.061)\end{array}$ \\
\hline Wholesale Trade & $\begin{array}{c}0.022 \\
(0.030)\end{array}$ & $\begin{array}{c}0.096^{*} \\
(0.052)\end{array}$ \\
\hline Retail Trade & $\begin{array}{l}-0.023 \\
(0.014)\end{array}$ & $\begin{array}{c}0.055 \\
(0.045)\end{array}$ \\
\hline Finance & $\begin{array}{l}-0.034^{* *} \\
(0.015)\end{array}$ & $\begin{array}{l}0.113^{* *} \\
(0.044)\end{array}$ \\
\hline Public Administration & $\begin{array}{c}-0.025 \\
(0.033)\end{array}$ & $\begin{array}{c}0.150 * \\
(0.078)\end{array}$ \\
\hline umber of Observations & 1,894 & 1,772 \\
\hline
\end{tabular}

Notes: For continuous covariates, entries are probability derivatives from probits, evaluated at the means of all variables. For binary covariates, entries are the change in predicted probabilities when the covariate increases from 0 to 1 . Standard errors are in parentheses.

*Statistically significant at the .10 level; **at the .05 level. between nonprofits and for-profits in the probabilities of promotion and expected promotion are unconditional. Since other variables correlated with both nonprofit status and promotions might explain these results, we turn to multivariate analysis. Two key control variables are worth mentioning. The first is tenure with the establishment, since a shorter average tenure in the nonprofit subsample (as revealed in Table 2) implies that nonprofit workers had been at risk for promotion for a shorter time than workers in the for-profit subsample. The second is worker ability, since this is surely correlated with promotion prospects and potentially differed across the two sectors. Since ability is rarely measurable in data sets spanning multiple firms, the typical approach is to treat educational attainment as a proxy or to use individual fixed effects when panel data are available. By itself, however, educational attainment is a crude proxy for worker ability, and a unique and attractive feature of the MCSUI data set is the presence of a job-specific performance rating for the most recently hired worker in the starting job. It is performance in this job that is relevant for determining whether the worker will be promoted or not. The survey also includes a measure of the performance of the "typical employee" in this same position.

Table 3 reports the results of probit models for the probabilities of promotion and expected promotion. Even in the presence of controls for worker performance, educational attainment, tenure, firm characteristics, and industry, the predicted probabilities associated with for-profit status are higher than those for nonprofit status, and the difference is statistically significantly different from zero. For-profit status is associated with an increase in the probability of promotion of 4.2 percentage points and with an increase in the probability of expected promotion of 12.5 percentage points, and in both cases the Z-statistics exceed 2.5. These magnitudes closely mirror those of the unconditional results reported in the first two rows of Table 2. The result that promotions were less likely in nonprofits than in for-profits is new and is the main result of this study. We also note that the signs of the effects of the performance 
ratings (positive for performance and negative for typical performance) are consistent with what we would expect if promotions are determined by relative performance as in internal promotion competitions. This result was documented by DeVaro (2006) using the same data set.

To gauge the robustness of the results in Table 3, we estimate a variety of alternative specifications. First, we include occupational controls for four broad occupational categories (professionals, sales workers, service workers, and laborers and operators). Second, we control for worker demographic characteristics (age, gender, race). Third, we control for characteristics of the job, in particular indicators for the frequency with which various tasks were performed. Fourth, we include an indicator for whether the position required a college degree. ${ }^{2}$ We also estimate specifications that control for whether or not the establishment offered each of 17 fringe benefits in the job in question. The nonprofit and for-profit sectors differ somewhat in fringe benefit provision, and even though there are not strong reasons to expect fringe benefit provision to be an important determinant of promotion probabilities, controlling for these differences seems a sensible precaution. Across all alternative specifications, the differences between nonprofits and for-profits in the probabilities of received and expected promotions remain statistically significantly different from $\mathrm{z}_{3}$ zero and of the same order of magnitude. ${ }^{3}$ We present some of these specifications in Table 4 , estimated on the subsample of observations in the service sector (results for the full sample are available upon request). The service sector is the largest sector in our data set and one in which nonprofits were heavily represented. This permits a within-industry analysis, which mitigates the concern that the

\footnotetext{
${ }^{2}$ Our basic model already controls for whether the most recent worker actually had a college degree or better. In the data, this usually but not always matches the employer's response to whether the job in question required a college degree.

${ }^{3}$ Later in the section we report results from models within educational and occupational subgroups and also models that control for establishment-level turnover variables.
}

concept of promotion might differ substantially across establishments in the estimation sample. Table 4 reveals that the main result that promotions were less likely in nonprofits is strong in the service sector.

Not all jobs offer opportunities for promotion. In particular, nonprofits are concentrated in labor-intensive services, and in 1990 accounted for " $64 \%$ of all hospital care, $56 \%$ of day care for children, $48 \%$ of primary medical care provided by maintenance organizations, $23 \%$ of nursing care, $20 \%$ of college and university education, and $10 \%$ of primary and secondary education" (Hansmann 1996:227) — sectors that are naturally flat in job hierarchy and, by definition, not conducive to job promotions. If nonprofit organizations are inherently flatter than for-profits, promotions will be possible less often in nonprofit jobs, and this might explain our main empirical finding. The MCSUI contains the following question: "If promoted, what would this employee's wage or salary be?" One possible answer was "no promotion possible." Cross-tabulating this response with nonprofit status reveals that nonprofits were more likely than for-profits to report that no promotion was possible. Fifteen percent of all establishments, $14.5 \%$ of for-profits, and $20.7 \%$ of nonprofits reported that no promotion was possible.

Even after we control for firm characteristics, industry, and occupation, nonprofits were more than 11 percentage points more likely than for-profits to report "no promotion possible," and this difference is statistically significantly different from zero. To determine whether our main result is sensitive to this difference, we estimate the probit models for promotion and expected promotion excluding from the sample those observations for which the respondent reported that no promotion was possible for the most recently hired worker. The main empirical finding that promotion probabilities were lower in nonprofits remains robust even with the exclusion of these observations. In the core specification, the for-profit effect in the promotion probit changes from 0.042 to 0.046 as a result of this exclusion, and the for-profit effect in the expected promotion probit changes from 0.125 to 0.111 . Both 
Table 4. Probits of the Probabilities of Promotion and Expected Promotion (Service Industry).

\begin{tabular}{|c|c|c|c|c|c|c|c|c|}
\hline \multirow[b]{2}{*}{ Independent Variable } & \multicolumn{4}{|c|}{ Promotions } & \multicolumn{4}{|c|}{ Expected Promotions } \\
\hline & (1) & (2) & (3) & (4) & (5) & (6) & (7) & $(8)$ \\
\hline For-Profit Status & $\begin{array}{l}0.083^{* *} \\
(0.022)\end{array}$ & $\begin{array}{l}0.084 * * \\
(0.022)\end{array}$ & $\begin{array}{l}0.073 * * \\
(0.021)\end{array}$ & $\begin{array}{l}0.066^{* * *} \\
(0.020)\end{array}$ & $\begin{array}{l}0.180 * * \\
(0.059)\end{array}$ & $\begin{array}{l}0.175^{* *} \\
(0.060)\end{array}$ & $\begin{array}{l}0.132 * * \\
(0.062)\end{array}$ & $\begin{array}{c}0.115^{*} \\
(0.063)\end{array}$ \\
\hline \multicolumn{9}{|l|}{ Employee Characteristics } \\
\hline Performance & $\begin{array}{c}0.084 \\
(0.087)\end{array}$ & $\begin{array}{c}0.085 \\
(0.086)\end{array}$ & $\begin{array}{c}0.126 \\
(0.092)\end{array}$ & $\begin{array}{c}0.083 \\
(0.087)\end{array}$ & $\begin{array}{c}0.168 \\
(0.185)\end{array}$ & $\begin{array}{c}0.188 \\
(0.185)\end{array}$ & $\begin{array}{c}0.259 \\
(0.186)\end{array}$ & $\begin{array}{c}0.129 \\
(0.183)\end{array}$ \\
\hline Typical Performance & $\begin{array}{c}0.033 \\
(0.087)\end{array}$ & $\begin{array}{c}0.032 \\
(0.089)\end{array}$ & $\begin{array}{c}0.059 \\
(0.088)\end{array}$ & $\begin{array}{c}0.066 \\
(0.087)\end{array}$ & $\begin{array}{l}-0.417 * * \\
(0.199)\end{array}$ & $\begin{array}{l}-0.400 * * \\
(0.197)\end{array}$ & $\begin{array}{l}-0.268 \\
(0.199)\end{array}$ & $\begin{array}{l}-0.241 \\
(0.187)\end{array}$ \\
\hline $\begin{array}{l}\text { High School Degree } \\
\text { or More }\end{array}$ & $\begin{array}{l}-0.003 \\
(0.026)\end{array}$ & $\begin{array}{l}-0.004 \\
(0.028)\end{array}$ & $\begin{array}{c}-0.002 \\
(0.026)\end{array}$ & $\begin{array}{c}-0.017 \\
(0.022)\end{array}$ & $\begin{array}{l}-0.069 \\
(0.056)\end{array}$ & $\begin{array}{c}-0.101 * \\
(0.061)\end{array}$ & $\begin{array}{c}-0.114 * \\
(0.064)\end{array}$ & $\begin{array}{l}-0.164 * * \\
(0.065)\end{array}$ \\
\hline $\begin{array}{l}\text { College Degree or } \\
\text { More }\end{array}$ & $\begin{array}{l}-0.083^{* *} \\
(0.025)\end{array}$ & $\begin{array}{l}-0.082 * * \\
(0.033)\end{array}$ & $\begin{array}{l}-0.089 * * \\
(0.031)\end{array}$ & $\begin{array}{l}-0.099 * * \\
(0.034)\end{array}$ & $\begin{array}{c}0.023 \\
(0.069)\end{array}$ & $\begin{array}{l}-0.016 \\
(0.080)\end{array}$ & $\begin{array}{l}-0.006 \\
(0.083)\end{array}$ & $\begin{array}{c}-0.096 \\
(0.091)\end{array}$ \\
\hline Tenure & $\begin{array}{l}0.111^{* *} \\
(0.048)\end{array}$ & $\begin{array}{l}0.110 * * \\
(0.049)\end{array}$ & $\begin{array}{l}0.094 * * \\
(0.047)\end{array}$ & $\begin{array}{l}0.093 * * \\
(0.044)\end{array}$ & $\begin{array}{l}-0.595^{* *} \\
(0.183)\end{array}$ & $\begin{array}{l}-0.611 * * \\
(0.179)\end{array}$ & $\begin{array}{l}-0.632 * * \\
(0.196)\end{array}$ & $\begin{array}{l}-0.658^{* *} \\
(0.174)\end{array}$ \\
\hline \multicolumn{9}{|l|}{ Firm Characteristics } \\
\hline Franchise & $\begin{array}{l}-0.002 \\
(0.042)\end{array}$ & $\begin{array}{l}-0.002 \\
(0.042)\end{array}$ & $\begin{array}{c}0.008 \\
(0.044)\end{array}$ & $\begin{array}{c}0.012 \\
(0.043)\end{array}$ & $\begin{array}{c}0.025 \\
(0.113)\end{array}$ & $\begin{array}{c}0.033 \\
(0.112)\end{array}$ & $\begin{array}{l}-0.014 \\
(0.125)\end{array}$ & $\begin{array}{l}-0.002 \\
(0.123)\end{array}$ \\
\hline Number of Sites & $\begin{array}{l}0.045^{* * *} \\
(0.014)\end{array}$ & $\begin{array}{l}0.045 * * \\
(0.015)\end{array}$ & $\begin{array}{l}0.040 * * \\
(0.014)\end{array}$ & $\begin{array}{l}0.032 * * \\
(0.014)\end{array}$ & $\begin{array}{c}0.296 \\
(0.190)\end{array}$ & $\begin{array}{c}0.262 \\
(0.190)\end{array}$ & $\begin{array}{c}0.142 \\
(0.175)\end{array}$ & $\begin{array}{c}0.183 \\
(0.184)\end{array}$ \\
\hline Establishment Size & $\begin{array}{l}-0.008 \\
(0.010)\end{array}$ & $\begin{array}{c}-0.008 \\
(0.010)\end{array}$ & $\begin{array}{l}-0.008 \\
(0.011)\end{array}$ & $\begin{array}{l}-0.006 \\
(0.013)\end{array}$ & $\begin{array}{l}0.041^{*} \\
(0.025)\end{array}$ & $\begin{array}{c}0.041^{*} \\
(0.024)\end{array}$ & $\begin{array}{c}0.024 \\
(0.039)\end{array}$ & $\begin{array}{c}0.036 \\
(0.041)\end{array}$ \\
\hline Union & $\begin{array}{c}0.021 \\
(0.038)\end{array}$ & $\begin{array}{c}0.021 \\
(0.039)\end{array}$ & $\begin{array}{c}0.020 \\
(0.019)\end{array}$ & $\begin{array}{c}0.020 \\
(0.033)\end{array}$ & $\begin{array}{c}-0.145 \\
(0.099)\end{array}$ & $\begin{array}{c}-0.135 \\
(0.099)\end{array}$ & $\begin{array}{l}-0.144 \\
(0.102)\end{array}$ & $\begin{array}{c}-0.125 \\
(0.101)\end{array}$ \\
\hline $\begin{array}{l}\text { Fraction of High-Skill } \\
\text { Employees }\end{array}$ & $\begin{array}{l}.070 \\
(0.043)\end{array}$ & $\begin{array}{c}0.068 \\
(0.043)\end{array}$ & $\begin{array}{c}0.048 \\
(0.040)\end{array}$ & $\begin{array}{c}0.044 \\
(0.035)\end{array}$ & $\begin{array}{l}0.239 * * \\
(0.085)\end{array}$ & $\begin{array}{l}0.233 * * \\
(0.085)\end{array}$ & $\begin{array}{l}0.261 * * \\
(0.090)\end{array}$ & $\begin{array}{c}0.174 * \\
(0.093)\end{array}$ \\
\hline Temporary Workers & $\begin{array}{c}-0.014 \\
(0.027)\end{array}$ & $\begin{array}{c}-0.013 \\
(0.026)\end{array}$ & $\begin{array}{c}-0.014 \\
(0.024)\end{array}$ & $\begin{array}{c}-0.013 \\
(0.023)\end{array}$ & $\begin{array}{l}0.180 * * \\
(0.055)\end{array}$ & $\begin{array}{l}0.182^{* * *} \\
(0.055)\end{array}$ & $\begin{array}{l}0.206 * * \\
(0.055)\end{array}$ & $\begin{array}{l}0.202^{* *} \\
(0.054)\end{array}$ \\
\hline Contract Workers & $\begin{array}{c}0.025 \\
(0.027)\end{array}$ & $\begin{array}{c}0.025 \\
(0.027)\end{array}$ & $\begin{array}{c}0.034 \\
(0.027)\end{array}$ & $\begin{array}{c}0.027 \\
(0.026)\end{array}$ & $\begin{array}{c}-0.001 \\
(0.058)\end{array}$ & $\begin{array}{c}0.010 \\
(0.058)\end{array}$ & $\begin{array}{c}0.000 \\
(0.058)\end{array}$ & $\begin{array}{c}-0.032 \\
(0.058)\end{array}$ \\
\hline \multicolumn{9}{|l|}{ Occupation Controls } \\
\hline Sales & & $\begin{array}{c}0.010 \\
(0.036)\end{array}$ & $\begin{array}{c}-0.010 \\
(0.033)\end{array}$ & $\begin{array}{c}-0.011 \\
(0.033)\end{array}$ & & $\begin{array}{c}0.020 \\
(0.067)\end{array}$ & $\begin{array}{c}0.054 \\
(0.069)\end{array}$ & $\begin{array}{c}0.064 \\
(0.075)\end{array}$ \\
\hline Services & & $\begin{array}{l}-0.004 \\
(0.051)\end{array}$ & $\begin{array}{c}-0.046^{*} \\
(0.024)\end{array}$ & $\begin{array}{l}-0.028 \\
(0.028)\end{array}$ & & $\begin{array}{l}-0.125 \\
(0.102)\end{array}$ & $\begin{array}{c}-0.166 \\
(0.104)\end{array}$ & $\begin{array}{c}-0.105 \\
(0.100)\end{array}$ \\
\hline Low-Skilled Laborers & & $\begin{array}{c}0.002 \\
(0.058)\end{array}$ & $\begin{array}{c}-0.036 \\
(0.038)\end{array}$ & $\begin{array}{c}-0.021 \\
(0.042)\end{array}$ & & $\begin{array}{c}-0.103 \\
(0.125)\end{array}$ & $\begin{array}{c}-0.163 \\
(0.132)\end{array}$ & $\begin{array}{c}-0.095 \\
(0.133)\end{array}$ \\
\hline
\end{tabular}

effects remain statistically significant at the $5 \%$ level. We conclude that, while it is true that nonprofits were more likely than for-profits to report that no promotion was possible, this fact is not driving our main empirical result.

\footnotetext{
${ }^{4}$ A related possibility is that a particular type of nonprofit job could be driving our main result. For example, consider nursing jobs in hospitals. Because of the nature of these jobs (nurses cannot be promoted to doctors), it might be that observations from one
}

One potentially important control variable that is omitted from the models in

occupation or a small number of detailed occupations are driving our result. This seems unlikely, given the information in Table 1 showing that nonprofit jobs are spread across all 19 occupational categories rather than concentrated in only a few of them. Nonetheless, as a robustness check, we re-estimated our main promotion probits on 19 subsamples, each of which excluded one of the 19 detailed occupational categories. The for-profit effect changed very little across these specifications. These results are available upon request. 
Table 4. Continued.

\begin{tabular}{|c|c|c|c|c|c|c|c|c|}
\hline \multirow[b]{2}{*}{ Independent Variable } & \multicolumn{4}{|c|}{ Promotions } & \multicolumn{4}{|c|}{ Expected Promotions } \\
\hline & (1) & (2) & (3) & (4) & (5) & (6) & (7) & $(8)$ \\
\hline \multicolumn{9}{|l|}{ Demographics } \\
\hline Age & & & $\begin{array}{c}-0.022 \\
(0.115)\end{array}$ & $\begin{array}{l}-0.019 \\
(0.104)\end{array}$ & & & $\begin{array}{l}-0.319 \\
(0.281)\end{array}$ & $\begin{array}{l}-0.280 \\
(0.268)\end{array}$ \\
\hline Male & & & $\begin{array}{c}0.022 \\
(0.026)\end{array}$ & $\begin{array}{c}0.033 \\
(0.026)\end{array}$ & & & $\begin{array}{l}0.138 * * \\
(0.056)\end{array}$ & $\begin{array}{l}0.153 * * \\
(0.052)\end{array}$ \\
\hline Black & & & $\begin{array}{c}0.057 \\
(0.052)\end{array}$ & $\begin{array}{c}0.044 \\
(0.047)\end{array}$ & & & $\begin{array}{l}0.161 * * \\
(0.055)\end{array}$ & $\begin{array}{l}0.138 * * \\
(0.054)\end{array}$ \\
\hline Hispanic & & & $\begin{array}{c}0.036 \\
(0.039)\end{array}$ & $\begin{array}{c}0.031 \\
(0.036)\end{array}$ & & & $\begin{array}{c}0.097 \\
(0.068)\end{array}$ & $\begin{array}{c}0.085 \\
(0.066)\end{array}$ \\
\hline Other Non-White & & & $\begin{array}{c}-0.037 \\
(0.036)\end{array}$ & $\begin{array}{l}-0.032 \\
(0.036)\end{array}$ & & & $\begin{array}{c}0.110 \\
(0.118)\end{array}$ & $\begin{array}{c}0.117 \\
(0.110)\end{array}$ \\
\hline \multicolumn{9}{|l|}{ Job Characteristics } \\
\hline Talk & & & & $\begin{array}{l}-0.005 \\
(0.028)\end{array}$ & & & & $\begin{array}{l}-0.111 * * \\
(0.056)\end{array}$ \\
\hline Phone & & & & $\begin{array}{c}0.042 \\
(0.027)\end{array}$ & & & & $\begin{array}{c}0.107 * \\
(0.063)\end{array}$ \\
\hline Math & & & & $\begin{array}{c}0.003 \\
(0.022)\end{array}$ & & & & $\begin{array}{c}-0.090 * \\
(0.051)\end{array}$ \\
\hline Compute & & & & $\begin{array}{c}0.010 \\
(0.023)\end{array}$ & & & & $\begin{array}{c}0.085 \\
(0.063)\end{array}$ \\
\hline Read & & & & $\begin{array}{c}0.033 \\
(0.022)\end{array}$ & & & & $\begin{array}{c}0.052 \\
(0.068)\end{array}$ \\
\hline Write & & & & $\begin{array}{c}0.036 \\
(0.024)\end{array}$ & & & & $\begin{array}{l}0.119 * * \\
(0.056)\end{array}$ \\
\hline $\begin{array}{l}\text { Position Requires College } \\
\text { Degree }\end{array}$ & & & & $\begin{array}{l}-0.009 \\
(0.037)\end{array}$ & & & & $\begin{array}{c}0.072 \\
(0.076)\end{array}$ \\
\hline Number of Observations & 683 & 679 & 636 & 628 & 642 & 638 & 602 & 594 \\
\hline
\end{tabular}

Notes: For continuous covariates, entries are probability derivatives evaluated at the means of all covariates. For binary covariates, entries measure the change in predicted probabilities when the dummy covariate increases from 0 to 1 .

*Statistically significant at the .10 level; **at the .05 level.

Tables 3 and 4 is the growth rate of the establishment. If, for example, the forprofit sector had a higher growth rate than the nonprofit sector during the analysis period, this could explain the difference in promotion rates between nonprofits and for-profits. Unfortunately, the MCSUI data do not include usable information on, for example, the growth rate of sales or revenues. However, we can control for establishment-wide employee growth, and this should be positively correlated with growth in sales. We address this issue in the following subsection.

\section{Do Rates of Turnover and Internal Hiring Differ Between For-Profits and Nonprofits?}

If rates of turnover differ between forprofits and nonprofits, this might explain the observed difference in promotion rates between the two sectors. The predicted relationship between turnover and promotion rates depends on a number of factors. Consider first a hierarchical organizational structure with fixed job slots. That is, each level of the job hierarchy involves a distinct set of tasks, so that promotions assign workers 
to different jobs with different sets of tasks. In such firms, in the absence of employment growth, both very low and very high rates of turnover are associated with low promotion probabilities. With low turnover rates, promotions are infrequent because opportunities for promotion only arise when vacancies are created by separations. With high turnover rates, the most recently hired worker has likely not been with the establishment long enough to receive a promotion. Furthermore, the worker is not expected to be with the establishment long enough to receive a promotion.

If job slots are flexible rather than fixed, then even with a hierarchical organizational structure, the relationship between turnover and promotion rates is somewhat different. Job slots are described as flexible when the production process does not necessitate having specific numbers of workers at each job level (for example, one manager, five assistant managers, and fifty production workers). When job slots are flexible, promotions reflect mostly changes in job title without large changes in tasks performed. Jobs in research are often described by flexible job slots. In firms with a hierarchical structure and flexible job slots, promotion rates can be high even when turnover is low, since promotion opportunities do not hinge on the creation of vacancies. Finally, other things equal, promotion rates should be lower in establishments with flatter organizational structures, regardless of turnover rates.

To summarize this discussion, the relationship between promotion rates and turnover depends on a number of factors, the most obvious being the organizational structure. A further complication is that even among establishments with equal rates of turnover, the distribution of these turnover rates across levels of a job hierarchy could be quite different between establishments. For example, one establishment might experience high turnover at the lowest rungs of the promotional job ladder and much lower rates of turnover higher up, whereas another establishment might experience roughly comparable turnover rates at all levels of the job hierarchy.

The MCSUI contains questions about the numbers of new hires, discharges, quits, layoffs, and recalls that occurred between the start of 1992 and the survey date. We use this information to construct measures of monthly hiring rates, separation rates, and net change in the work force for each establishment. As seen in Table 2, only the separation rate has a difference in means between nonprofits and for-profits that is statistically significantly different from zero at the $5 \%$ level. For-profits had higher monthly rates of separation during the sample period than did nonprofits. However, including the separation rate as a control in the promotion probability models of Table 3 leaves the main result largely unchanged. The effects of for-profit status on the probabilities of promotion and expected promotion from the first row of Table 3 change to 0.046 ( $\mathrm{Z}=$ 2.94) and $0.113(Z=2.16)$, respectively. If hiring rate, separation rate, and net change are included simultaneously as controls, these effects change to $0.041(Z=2.30)$ and 0.090 $(Z=1.58)$. While the effect of for-profit status on expected promotions is no longer statistically significantly different from zero in the presence of these three controls, its magnitude diminishes only modestly relative to its magnitude in Table 3, and the Z-statistic still exceeds 1.5.

As an additional robustness check, given that some for-profits had very high separation rates, we estimate the models in Table 3 for the subsample of observations with separation rates less than 75 . That yields a sample size of 1,642 in the promotion model and 1,532 in the expected promotion model. The forprofit result in the promotion model is 0.044 $(Z=2.75)$, and the result in the expected promotion model is $0.113(\mathrm{Z}=2.17)$.

The evidence suggests that, at least at the level of the entire establishment, differences in turnover between nonprofits and for-profits cannot explain our main result. However, we caution that since our focus is on the probabilities of promotion and expected promotion for the most recently hired worker, the more relevant measures of turnover would pertain only to workers of that skill type and to workers located at higher rungs of the promotional hierarchy. Establishments with high overall turnover rates might still have 
experienced low turnover for certain jobs, such as the one into which the most recent worker was hired. Unfortunately, the data provide no information about turnover rates in each establishment by hierarchical level.

We now turn to the issue of internal hiring, which relates closely to promotions. The MCSUI data lack a direct measure of internal hiring policies. The only information available is the employer's answer to the question, "Do you have formal procedures for posting internal job openings and soliciting applications for filling them?" As a proxy for internal hiring policies, this measure is subject to biases in both directions. Some organizations may have engaged in significant internal hiring, even in the absence of formal procedures for posting internal job openings. Alternatively, some may have engaged in relatively little internal hiring, even with formal procedures in place. Sixty percent of the respondents reported having formal procedures for internal hiring, though nonprofits were 37 percentage points more likely than for-profits to have these procedures. After controlling for firm characteristics and industry, this difference diminishes to $30 \%$ with a Z-statistic exceeding 7 .

One interpretation of this result is that nonprofits were more likely than for-profits to have internal hiring policies characterized by high rates of internal promotion, though we caution that having formal procedures in place for internal hiring is not the same as using them. It might appear that a higher rate of internal hiring in nonprofits is inconsistent with the lower rates of promotion we have documented in nonprofits, but that is not necessarily so. Suppose that nonprofits rely on promotions mainly to achieve optimal job assignment (as opposed to incentives). Optimal job assignment might be achieved and maintained for a long time, with no need for job reassignments through further promotions. In this context, promotion rates would be low even if all hiring were done internally. Of course, promotions would create weak incentives in this context. For promotions to create incentives, they need to occur with some frequency, so that workers believe there is reasonable chance of promotion within the foreseeable future. The prospect of getting promoted to manager 25 years from now provides little motivation to work hard today, even if the firm engages almost exclusively in internal hiring. In contrast, the role of promotions in achieving optimal job assignment does not depend on how frequently they occur in an organization.

\section{Do the Differences in Promotion Rates Between Nonprofits and For-Profits Exist for Both High- and Low-Skilled Workers?}

We estimate the promotion probits from Table 3 on subsamples disaggregated by skill level, defining workers with a high school degree or less as low-skilled and all other workers as high-skilled. As revealed in Table 5 , for high-skilled workers the probabilities of promotion and expected promotion were higher in for-profits than in nonprofits. Specifically, for-profit status was associated with an increase of nearly 5 percentage points in the probability of promotion and an increase of nearly 14 percentage points in the probability of expected promotion. For low-skilled workers, in contrast, there is no evidence of a positive relationship between for-profit status and promotions. Furthermore, though for-profit status increased the probability of expected promotion by 10.5 percentage points, this is statistically significant only at the $10 \%$ level.

We also consider occupational groups of differing skill levels, defining four broad occupational groups based on a survey question that asked what job the most recently hired worker was hired to do. Verbal descriptions were converted to 2-, 3-, and 4-digit codes according to the 1980 SOC for the final release of the MCSUI data. Our four broad groups, in roughly descending order by skill level, are as follows:

Professionals: Administrative, engineering, scientific, teaching, and related occupations, including creative artists

Sales: Technical, clerical, sales, and related occupations; precision production, craft and repair

Services: Service occupations, including military occupations

Low-skilled: Operators, fabricators, laborers; farming, forestry, fishing, and hunting occupations\} 
Table 5. Probabilities of Promotion and Expected Promotion by Education Level.

\begin{tabular}{|c|c|c|c|c|}
\hline \multirow[b]{2}{*}{ Independent Variable } & \multicolumn{2}{|c|}{ Promotions } & \multicolumn{2}{|c|}{ Expected Promotions } \\
\hline & Skilled & Low-Skilled & Skilled & Low-Skilled \\
\hline For-Profit Status & $\begin{array}{l}0.048^{* *} \\
(0.014)\end{array}$ & $\begin{array}{c}0.021 \\
(0.029)\end{array}$ & $\begin{array}{c}0.139 * * \\
(0.065)\end{array}$ & $\begin{array}{c}0.105^{*} \\
(0.064)\end{array}$ \\
\hline \multicolumn{5}{|l|}{ Employee Characteristics } \\
\hline Employee Performance & $\begin{array}{c}0.105^{*} \\
(0.057)\end{array}$ & $\begin{array}{l}0.245^{* *} \\
(0.087)\end{array}$ & $\begin{array}{l}0.503 * * \\
(0.145)\end{array}$ & $\begin{array}{l}0.369 * * \\
(0.126)\end{array}$ \\
\hline Typical Performance & $\begin{array}{c}-0.048 \\
(0.058)\end{array}$ & $\begin{array}{c}-0.094 \\
(0.071)\end{array}$ & $\begin{array}{c}-0.391 * * \\
(0.168)\end{array}$ & $\begin{array}{c}-0.220 \\
(0.152)\end{array}$ \\
\hline Tenure & $\begin{array}{c}0.182 * * \\
(0.039)\end{array}$ & $\begin{array}{l}0.134 * * \\
(0.051)\end{array}$ & $\begin{array}{c}-0.458^{* *} \\
(0.135)\end{array}$ & $\begin{array}{c}-0.433^{* *} \\
(0.112)\end{array}$ \\
\hline \multicolumn{5}{|l|}{ Firm Characteristics } \\
\hline Franchise & $\begin{array}{c}-0.028 \\
(0.017)\end{array}$ & $\begin{array}{c}0.058 \\
(0.055)\end{array}$ & $\begin{array}{c}-0.037 \\
(0.094)\end{array}$ & $\begin{array}{c}0.059 \\
(0.059)\end{array}$ \\
\hline Number of Sites & $\begin{array}{c}0.027 * * \\
(0.010)\end{array}$ & $\begin{array}{c}-0.271 \\
(0.183)\end{array}$ & $\begin{array}{c}0.094 \\
(0.148)\end{array}$ & $\begin{array}{c}0.066^{*} \\
(0.036)\end{array}$ \\
\hline Establishment Size & $\begin{array}{c}-0.003 \\
(0.005)\end{array}$ & $\begin{array}{c}-0.017 \\
(0.020)\end{array}$ & $\begin{array}{c}0.075^{*} \\
(0.044)\end{array}$ & $\begin{array}{c}0.070 \\
(0.050)\end{array}$ \\
\hline Union & $\begin{array}{c}-0.057 * \\
(0.031)\end{array}$ & $\begin{array}{c}-0.033 \\
(0.028)\end{array}$ & $\begin{array}{c}-0.149 * \\
(0.089)\end{array}$ & $\begin{array}{c}-0.136^{* *} \\
(0.061)\end{array}$ \\
\hline Fraction of High-Skill Employees & $\begin{array}{c}-0.046 \\
(0.028)\end{array}$ & $\begin{array}{c}0.032 \\
(0.048)\end{array}$ & $\begin{array}{c}0.177 * * \\
(0.070)\end{array}$ & $\begin{array}{c}0.064 \\
(0.081)\end{array}$ \\
\hline Temporary Workers & $\begin{array}{l}-0.021 \\
(0.017)\end{array}$ & $\begin{array}{c}0.017 \\
(0.022)\end{array}$ & $\begin{array}{l}0.169 * * \\
(0.044)\end{array}$ & $\begin{array}{c}-0.026 \\
(0.044)\end{array}$ \\
\hline Contract Workers & $\begin{array}{c}0.003 \\
(0.018)\end{array}$ & $\begin{array}{c}-0.0003 \\
(0.022)\end{array}$ & $\begin{array}{c}-0.002 \\
(0.045)\end{array}$ & $\begin{array}{c}0.0001 \\
(0.043)\end{array}$ \\
\hline Number of Observations & 942 & 952 & 888 & 884 \\
\hline
\end{tabular}

Notes: Results from probit models. All models also include industry controls. The "Skilled" sample consists of those most recent hires who have more than a high school degree. The "Unskilled" sample consists of those most recent hires who have less than a high school degree. For continuous covariates, cell entries are probability derivatives evaluated at the means of all variables for continuous variables. For binary covariates, cell entries measure the change in predicted probabilities when the covariate increases from 0 to 1 . Standard errors are in parentheses.

*Statistically significant at the .10 level; **at the .05 level.

As revealed in Table 6, the probabilities of promotion and expected promotion were higher in for-profits than in nonprofits for all but the least-skilled occupational group, though these differences are statistically significant only in the case of professional occupations (for promotions) and sales occupations (for expected promotions).

\section{Summary}

Our main empirical result that received and expected promotions were more likely in for-profits than in nonprofits is statistically significant in magnitude, precisely estimated, and robust with respect to the inclusion of other control variables that potentially explain received and expected promotions. Excluding observations for which it was reported that "no promotion is possible" does not eliminate the result, nor does dropping individual occupations from the sample. The result also holds strongly in a sample restricted to the service industry. The result is strongest for high-skilled jobs and is absent for the lowest-skilled occupations. Controlling for measures of establishment-wide turnover does not change the result. Finally, for-profits were less likely than nonprofits to have formal 
Table 6. Probabilities of Promotion and Expected Promotion by Occupation.

\begin{tabular}{|c|c|c|c|c|c|c|c|c|}
\hline \multirow[b]{2}{*}{ Independent Variable } & \multicolumn{4}{|c|}{ Promotions } & \multicolumn{4}{|c|}{ Expected Promotions } \\
\hline & $A$ & $B$ & $C$ & $D$ & $A$ & $B$ & $C$ & $D$ \\
\hline For-Profit Status & $\begin{array}{l}0.044 * * \\
(0.023)\end{array}$ & $\begin{array}{c}0.034 \\
(0.021)\end{array}$ & $\begin{array}{c}0.051 \\
(0.031)\end{array}$ & $\begin{array}{l}-0.027 \\
(0.057)\end{array}$ & $\begin{array}{c}0.134 \\
(0.102)\end{array}$ & $\begin{array}{l}0.141 * * \\
(0.059)\end{array}$ & $\begin{array}{c}0.079 \\
(0.123)\end{array}$ & $\begin{array}{l}-0.063 \\
(0.067)\end{array}$ \\
\hline \multicolumn{9}{|l|}{ Employee Characteristics } \\
\hline Performance & $\begin{array}{l}0.429 * * \\
(0.154)\end{array}$ & $\begin{array}{l}0.152 * * \\
(0.054)\end{array}$ & $\begin{array}{l}-0.108 \\
(0.105)\end{array}$ & $\begin{array}{c}0.178 \\
(0.163)\end{array}$ & $\begin{array}{c}0.468^{*} \\
(0.273)\end{array}$ & $\begin{array}{l}0.509 * * \\
(0.114)\end{array}$ & $\begin{array}{l}-0.420 \\
(0.318)\end{array}$ & $\begin{array}{c}0.057 \\
(0.119)\end{array}$ \\
\hline Relative Performance & $\begin{array}{c}0.075 \\
(0.076)\end{array}$ & $\begin{array}{l}-0.124 * * \\
(0.058)\end{array}$ & $\begin{array}{c}0.068 \\
(0.089)\end{array}$ & $\begin{array}{c}-0.178 \\
(0.160)\end{array}$ & $\begin{array}{l}-0.758^{* *} \\
(0.301)\end{array}$ & $\begin{array}{l}-0.254 * * \\
(0.128)\end{array}$ & $\begin{array}{l}-0.067 \\
(0.372)\end{array}$ & $\begin{array}{c}0.018 \\
(0.140)\end{array}$ \\
\hline $\begin{array}{l}\text { High School Degree } \\
\text { or More }\end{array}$ & $\begin{array}{l}-0.034 \\
(0.024)\end{array}$ & $\begin{array}{c}0.004 \\
(0.017)\end{array}$ & $\begin{array}{c}0.006 \\
(0.032)\end{array}$ & $\begin{array}{c}0.064 \\
(0.058)\end{array}$ & $\begin{array}{c}0.095 \\
(0.101)\end{array}$ & $\begin{array}{l}-0.019 \\
(0.034)\end{array}$ & $\begin{array}{c}-0.067 \\
(0.098)\end{array}$ & $\begin{array}{c}0.009 \\
(0.040)\end{array}$ \\
\hline $\begin{array}{l}\text { College Degree or } \\
\text { More }\end{array}$ & $\begin{array}{l}-0.051 \\
(0.032)\end{array}$ & $\begin{array}{l}-0.048^{* *} \\
(0.019)\end{array}$ & $\begin{array}{c}0.007 \\
(0.047)\end{array}$ & $\begin{array}{c}0.052 \\
(0.108)\end{array}$ & $\begin{array}{c}0.141 \\
(0.104)\end{array}$ & $\begin{array}{l}-0.016 \\
(0.046)\end{array}$ & $\begin{array}{l}-0.111 \\
(0.204)\end{array}$ & $\begin{array}{c}-0.017 \\
(0.113)\end{array}$ \\
\hline Tenure & $\begin{array}{l}0.148 * * \\
(0.066)\end{array}$ & $\begin{array}{l}0.133^{* *} \\
(0.040)\end{array}$ & $\begin{array}{l}0.227 * * \\
(0.094)\end{array}$ & $\begin{array}{c}0.242 \\
(0.237)\end{array}$ & $\begin{array}{l}-0.738^{* *} \\
(0.205)\end{array}$ & $\begin{array}{l}-0.413^{* *} \\
(0.095)\end{array}$ & $\begin{array}{l}-0.695 * * \\
(0.283)\end{array}$ & $\begin{array}{c}-0.074 \\
(0.134)\end{array}$ \\
\hline \multicolumn{9}{|l|}{ Firm Characteristics } \\
\hline Franchise & & $\begin{array}{c}0.030 \\
(0.041)\end{array}$ & $\begin{array}{l}-0.006 \\
(0.032)\end{array}$ & $\begin{array}{l}-0.021 \\
(0.031)\end{array}$ & $\begin{array}{l}-0.427 * * \\
(0.173)\end{array}$ & $\begin{array}{c}0.085^{*} \\
(0.046)\end{array}$ & $\begin{array}{c}0.010 \\
(0.119)\end{array}$ & $\begin{array}{c}0.085 \\
(0.062)\end{array}$ \\
\hline Number of Sites & $\begin{array}{c}0.007 \\
(0.006)\end{array}$ & $\begin{array}{l}-0.081 * * \\
(0.038)\end{array}$ & $\begin{array}{l}-0.342 * * \\
(0.154)\end{array}$ & $\begin{array}{r}-1.111^{*} \\
(0.629)\end{array}$ & $\begin{array}{c}0.215 \\
(0.291)\end{array}$ & $\begin{array}{c}0.102 \\
(0.071)\end{array}$ & $\begin{array}{c}0.075 \\
(0.052)\end{array}$ & $\begin{array}{l}1.973^{* *} \\
(0.906)\end{array}$ \\
\hline Establishment Size & $\begin{array}{c}-0.004 \\
(0.004)\end{array}$ & $\begin{array}{l}-0.002 \\
(0.012)\end{array}$ & $\begin{array}{c}0.007 \\
(0.008)\end{array}$ & $\begin{array}{l}-0.005 \\
(0.019)\end{array}$ & $\begin{array}{l}0.043^{*} \\
(0.026)\end{array}$ & $\begin{array}{l}0.116^{* *} \\
(0.043)\end{array}$ & $\begin{array}{c}0.052 \\
(0.061)\end{array}$ & $\begin{array}{c}0.131 * \\
(0.070)\end{array}$ \\
\hline Union & $\begin{array}{c}0.052 \\
(0.037)\end{array}$ & $\begin{array}{l}-0.051 * * \\
(0.025)\end{array}$ & $\begin{array}{l}-0.102 * * \\
(0.051)\end{array}$ & $\begin{array}{c}-0.038 \\
(0.053)\end{array}$ & $\begin{array}{l}-0.337 * * \\
(0.130)\end{array}$ & $\begin{array}{l}-0.140 * * \\
(0.066)\end{array}$ & $\begin{array}{c}0.254^{*} \\
(0.139)\end{array}$ & $\begin{array}{c}-0.077 \\
(0.055)\end{array}$ \\
\hline $\begin{array}{l}\text { Fraction of High-Skill } \\
\text { Employees }\end{array}$ & $\begin{array}{l}-0.068 \\
(0.045)\end{array}$ & $\begin{array}{c}-0.0002 \\
(0.035)\end{array}$ & $\begin{array}{c}0.043 \\
(0.075)\end{array}$ & $\begin{array}{c}0.051 \\
(0.069)\end{array}$ & $\begin{array}{l}0.243 * * \\
(0.123)\end{array}$ & $\begin{array}{c}0.065 \\
(0.059)\end{array}$ & $\begin{array}{c}0.014 \\
(0.190)\end{array}$ & $\begin{array}{c}-0.036 \\
(0.101)\end{array}$ \\
\hline Temporary Workers & $\begin{array}{c}-0.002 \\
(0.024)\end{array}$ & $\begin{array}{c}0.009 \\
(0.018)\end{array}$ & $\begin{array}{c}-0.003 \\
(0.033)\end{array}$ & $\begin{array}{c}-0.001 \\
(0.019)\end{array}$ & $\begin{array}{l}0.213^{* *} \\
(0.078)\end{array}$ & $\begin{array}{l}0.099 * * \\
(0.036)\end{array}$ & $\begin{array}{c}-0.174^{*} \\
(0.096)\end{array}$ & $\begin{array}{c}0.023 \\
(0.042)\end{array}$ \\
\hline Contract Workers & $\begin{array}{c}-0.012 \\
(0.020)\end{array}$ & $\begin{array}{c}0.015 \\
(0.020)\end{array}$ & $\begin{array}{c}-0.008 \\
(0.028)\end{array}$ & $\begin{array}{c}-0.012 \\
(0.022)\end{array}$ & $\begin{array}{c}-0.120 \\
(0.094)\end{array}$ & $\begin{array}{c}0.027 \\
(0.037)\end{array}$ & $\begin{array}{c}0.029 \\
(0.090)\end{array}$ & $\begin{array}{c}0.006 \\
(0.041)\end{array}$ \\
\hline Number of Observations & 269 & 1,071 & 243 & 286 & 251 & 1,005 & 232 & 261 \\
\hline
\end{tabular}

Notes: $\mathrm{A}=$ Professionals, $\mathrm{B}=$ Sales, $\mathrm{C}=$ Services, and $\mathrm{D}=$ Low-skilled occupations as described in the text. For continuous covariates, cell entries are probability derivatives evaluated at the means of all variables. For binary covariates, cell entries measure the change in predicted probabilities when the binary covariate increases from 0 to 1. The Franchise variable is dropped in the first column due to collinearity. Standard errors are in parentheses.

*Statistically significant at the .10 level; **at the .05 level.

procedures for internal hiring. This might be interpreted as indirect evidence that for-profits did not have greater rates of internal hiring and promotion, though we caution that the measure of procedures is indirect and may not reflect actual hiring practices.

While we have controlled for a large number of factors, we cannot rule out the possibility that an omitted variable correlated with both promotion rates and for-profit status explains the empirical result. The fact that many observable characteristics of workers and organizations differed by sector, as revealed in Table 2, suggests that unobservable characteristics may also have differed by sector in a way that influenced our result. For example, while our data are unusual in allowing us to control for performance in the pre-promotion job using subjective performance ratings, it is quite possible that these ratings do not fully reflect the qualities employers actually observed and used as a basis for promotion decisions (for 
example, motivation or tastes for particular types of work).

Similarly, unmeasured characteristics of employers that are correlated with both nonprofit status and promotion decisions may also influence our result. Selection of workers into nonprofits is determined by the employer's hiring behavior as well as by worker preferences. Some recent empirical evidence suggests that nonprofit and for-profit employers differ in their recruitment of new hires. DeVaro (2005) found that recruiting campaigns in the nonprofit sector are longer in duration and involve more recruiting methods than those in the for-profit sector. One interpretation is that nonprofit employers seek to attract a particular type of worker who is sympathetic to and motivated by the organizational mission. The need for a highly specific match would necessitate a more vigorous recruitment campaign involving more methods and suggests that a longer search must be conducted, and more intensive screening methods applied, before finding the right person.

In addition to these issues of unobserved heterogeneity, another potential source of concern is that in our multivariate analyses the sample size is cut sharply due to missing values. Mitigating this concern, in our view, is the fact that we find evidence of a statistically significant effect across virtually all specifications we estimate, regardless of the size of the subsample and the included control variables. Furthermore, the magnitude of the for-profit effect varies relatively little across these specifications even when large numbers of observations disappear because of missing values. This leads us to believe that the main cost of missing values in this context is reduced precision in our estimates.

\section{Related Empirical Questions Concerning Incentives}

We now investigate three empirical questions concerning incentives that complement the main empirical question of how promotion rates differed between the nonprofit and for-profit sectors.

\section{Are Promotions Equally Likely to Be Based on Merit and Job Performance in the Two Sectors?}

Promotions create stronger incentives when they are closely tied to worker performance. The MCSUI includes questions about the extent to which promotions (out of the position held by the most recently hired worker) were based on "merit and job performance," on "seniority," and on "affirmative action." For all three questions, responses were coded as $1=$ "not at all," 2 = "somewhat," 3 = "mostly." We estimate ordered probits of these three dependent variables on the for-profit indicator. The for-profit coefficients (with standard errors in parentheses) are $0.469(0.120)$ for merit and job performance, $-0.028(0.086)$ for seniority, and $-0.268(0.088)$ for affirmative action. If controls for firm characteristics and industry are included in the ordered probits, the results change to $0.359(0.149)$ for merit and job performance, -0.041 $(0.130)$ for seniority, and $-0.324(0.123)$ for affirmative action.

These point estimates suggest that forprofit status was associated with a higher probability that promotions were based on merit and lower probabilities that promotions were based on seniority or affirmative action, though the seniority effect is not statistically significant. For the two variables with statistically significant effects, the magnitudes implied by the coefficients (in the specifications that include controls) are as follows. For the degree to which promotions were based on merit and job performance, for-profit status is associated with a decrease of 2.3 percentage points in the probability of a response of "not at all," a decrease of 5.6 percentage points in the probability of a response of "somewhat," and an increase of 7.9 percentage points in the probability of a response of "mostly." For the degree to which promotions were based on affirmative action, for-profit status is associated with an increase of 12.8 percentage points in the probability of "not at all," a decrease of 8 percentage points in the probability of "somewhat," and a decrease of 4.8 percentage points in the probability of "mostly." 
All covariates are evaluated at their means in these calculations.

We also estimate a probit model for received promotions, using the performance levels of the most recently hired worker and of the typical worker in that same job (namely, the pre-promotion job) as independent variables, along with controls for worker and firm characteristics and industry. We estimate this model on the for-profit and nonprofit subsamples separately. In the for-profit subsample, a ten-point increase in worker performance on the 100-point scale is associated with an increase of 2.3 percentage points $(\mathrm{Z}=3.75)$ in the probability of promotion. In contrast, in the nonprofit subsample a ten-point increase in performance is associated with only a 0.14 percentage-point increase in promotion probability, and this is not statistically significant $(Z=0.75)$. In both subsamples, a ten-point increase in the performance of the typical employee has a statistically insignificant negative effect on promotion probability, though the effect is larger in magnitude in the for-profit subsample $(-0.58$ with $Z=1.19)$ than in the nonprofit subsample $(-0.03$ with $Z=0.13)$. When these results are combined with the results on the employers' responses to questions about the extent to which promotions were based on merit and job performance, as opposed to seniority or affirmative action, what emerges is the clear implication that merit and job performance in the pre-promotion job were less often the basis for promotions in nonprofits than in for-profits.

\section{Do Wage Levels and Growth Rates, within and between Hierarchical Levels, Differ between the Nonprofit and For-Profit Sectors?}

The empirical literature on nonprofits has focused heavily on differences in compensation between the nonprofit and for-profit sectors. The main aim of such research has been to test the proposition that workers who prefer employment that contributes to a positive social mission will accept lower wages to work in such jobs, other things equal. That is, a compensating differential should emerge between nonprofits and for- profits. Evidence from a survey of student attitudes is consistent with this proposition. Rawls, Ullrich, and Nelson (1975) presented survey evidence on graduate students in business at Vanderbilt University showing that students claiming to place less emphasis on economic wealth were more likely to end up in nonprofit jobs.

Studies of wage differentials between the two sectors have used a wide range of data sources, including samples of lawyers, executives, daycare providers, and recent Cornell University graduates, as well as broader samples from the Current Population Survey, the Survey of Job Characteristics, and the decennial Census. Although the estimated wage differentials in this literature tend to favor for-profit workers, some studies have found either no differential or a differential favoring nonprofit workers. For example, the recent study of child care workers by Mocan and Tekin (2003) found a substantial compensation premium in favor of nonprofit jobs. Weisbrod (1983), who compared the wages of public-sector and private-sector lawyers, found higher wages for the latter, though Goddeeris (1988) used the same data and found no wage difference between the groups after accounting for self-selection. In a study using over four million observations from the 1990 Census, the broadest sample to date in this literature, Leete (2001) found no evidence of an economy-wide nonprofit wage differential, though within particular industries she found wage differentials, some positive and some negative. In summary, the empirical literature suggests that there is no for-profit/nonprofit wage differential at the economy-wide level, but that a differential does occur within some particular industries, with for-profits perhaps having the advantage more often than nonprofits.

In this subsection we analyze differences in wage levels between the two sectors and also differences in wage growth (both within-job and across hierarchical levels when a promotion occurs). We consider two dependent variables measuring wage levels: the $\log$ of the most recently hired worker's starting wage, and the log of this worker's current wage at the time of the survey. The reported time frame for all MCSUI wage questions is 
either hourly, weekly, monthly, or annually, and we convert all responses to hourly wages measured in 1990 dollars, deflated using the CPI-UX. Results are displayed in the first two columns of Table 7. The coefficient on the for-profit indicator in both models reveals that in the presence of controls there are no statistically significant differences between nonprofit and for-profit workers, either in starting wages or in current wages.

For wage growth, we consider both intralevel, or within-job, potential wage growth that is expected to occur in the absence of promotion and inter-level wage growth that occurs as a result of promotions. Our measure of potential within-job wage growth relies on responses to the following MCSUI question: "What is the highest wage or salary that any employee in this position could expect to be paid without promotion?" The question refers to the position into which the most recently hired worker was hired. We take the difference between the log of the highest wage obtainable in the position and the log of the starting wage as our measure of potential within-job wage growth. The results, displayed in the third column of Table 7 , indicate no statistically significant difference between the two sectors. ${ }^{5}$

Casual observation and previous empirical work (for example, Gerhart and Milkovich 1989; Lazear 1992; McCue 1996) suggest that promotions are associated with large wage increases, but there is no prior empirical evidence on whether the magnitude of the increase differs systematically between the nonprofit and for-profit sectors. To assess this, we construct a measure of the wage increase attached to promotion. For work-

\footnotetext{
${ }^{5}$ The average within-job wage difference (as opposed to the difference in $\operatorname{logs}$ ) in nonprofits was $\$ 4.04$ per hour, while in for-profits it was $\$ 3.33$ per hour. This difference of $\$ 0.72$ per hour is statistically significantly different from zero at the $10 \%$ level, with a t-statistic of 1.95. However, controlling for only one other variable, establishment size, renders the difference in means no longer statistically significant even at the $10 \%$ level. Controlling for the full set of firm characteristics switches the sign of the difference in means and reduces the magnitude to $\$ 0.70$ per hour, again not statistically significant.
}

ers who had received a promotion by the survey date, we define this spread as the difference between the worker's current wage and starting wage. For workers who had not received a promotion, we subtract the worker's current wage from the wage that the employer reported the worker was expected to receive if promoted. Using this measure of the promotion wage spread, defined for both promoted and non-promoted workers, we find that the average increase in hourly wages from promotion was $\$ 3.25$ in for-profits and $\$ 4.09$ in nonprofits, with the difference of $\$ 0.83$ not being statistically significant ( $\mathrm{p}$ value $=0.378$ ). Thus, workers in for-profits and nonprofits received large wage increases of similar magnitude.

As an alternative way to assess inter-job wage growth that does not rely on a subjective measure of the wage a worker was expected to receive if promoted, we also estimate a regression in which the dependent variable is the percentage wage change from the starting date to the survey date. Independent variables include worker and firm characteristics, an indicator for whether a promotion was received by the survey date, and the interaction of the promotion dummy and the for-profit status dummy. Results are displayed in the fourth column of Table 7. The coefficient on the interaction term is negative, indicating that the average wage change accompanying promotions was lower in for-profits than in nonprofits, though this effect is not statistically significant at conventional levels. Controlling for the starting wage in this regression yields the same result.

To summarize, our results indicate no statistically significant differences between nonprofits and for-profits in wage growth, either within jobs or across levels of a promotional hierarchy. These results cast doubt on the hypothesis that in the nonprofit and forprofit sectors promotions mean two different things. One hypothesis is that job hierarchies are more finely sliced in the for-profit sector than in the nonprofit sector, so that a typical nonprofit organization may have a few big levels whereas a similar for-profit firm may have a larger number of smaller levels. If true, this might provide an explanation for our main result that promotions were less 
likely in nonprofits, since a worker could have reached the same level either from a single promotion in a nonprofit or from a number of smaller promotions in a forprofit. We would then expect promotions in nonprofits to have been characterized by larger wage increases than promotions in otherwise similar for-profits, and we would also expect higher within-job wage growth in the nonprofit sector. Our results do not support this view. Furthermore, the results suggest that nonprofits were not relying more than for-profits on within-job wage growth (as opposed to promotions) to create incentives. The results indicate that the two sectors were similar in the compensation associated with promotions (in both sectors, promotions involved large wage increases of comparable magnitudes), in within-job wage growth prospects, and in wage levels.

\section{Do Nonprofits and For-Profits Differ in Their Use of Output- Contingent Incentive Contracts?}

Output-based pay schemes could be based on output measured either at the level of individual workers (for example, piece-rate schemes or individual performance bonuses) or at broader levels such as the entire establishment or firm (for example, profit sharing and analogous schemes). While profit-sharing plans, by definition, cannot be observed in nonprofits, actual measures of organizational performance in nonprofits are numerous. Examples include the ratio of program service expense to total expense; income growth; changes in funding level; cost savings; changes in public awareness, quality of service, and fundraising volume; and customer satisfaction, or trustworthiness (Hallock 2000). Key to the attractiveness to employers of output-based schemes (whether based on output measures at the individual worker level or at the firm level) is the cost of measuring output. Output is generally more difficult to measure at the organizational level in nonprofits than in for-profits, and the problems associated with such output-based pay using imperfect performance measures have been clearly noted in the nonprofit literature (for example,
Weisbrod 1988, 1989; Cleverley and Mullen 1982; Oster 1996; Hallock 2000), as well as more generally in the agency literature (for example, Baker 1992). ${ }^{6}$

Recent evidence that the link between economic performance and pay for top managers is quite weak in nonprofit hospitals is found in Bertrand, Hallock, and Arnould (2005), though the authors present evidence that this link strengthens with higher rates of HMO penetration. Roomkin and Weisbrod (1999) found differences between nonprofit and for-profit hospitals in the base pay/bonus composition of managerial compensation, with bonuses higher in absolute and relative terms in for-profit hospitals. Further evidence that pay and performance are not as tightly linked in nonprofits as in for-profits was reported by Werner and Gemeinhardt (1995). They studied a sample of 1,811 workers from 69 nonprofits in the Houston metropolitan area. The nonprofit jobs included those in employment and training, youth development, mental health, social service, education, arts and culture, and environmental organizations. Werner and Gemeinhardt's basic conclusion was that nonprofits did not tie compensation to organizational performance, as measured by average annual budget growth and administrative efficiency.

The discussion thus far indicates that output-contingent contracts based on output measures at the organizational level are less prevalent in the nomprofit sector.

In the MCSUI, the respondent employer was asked if the most recently hired worker received "anything in addition to the wage or salary, such as tips, bonuses, or other supplements." An affirmative response was given in $66.8 \%$ of for-profits and $21.1 \%$ of nonprofits, and the difference in means is statistically significantly different from zero $(\mathrm{t}>15)$. While this suggests that for-profits were more

\footnotetext{
${ }^{6}$ Easley and O'Hara (1983) took as given that organizational output is harder to measure in nonprofits than in for-profits and argued, based on reasoning from Hansmann (1980), that the co-existence of forprofits and nonprofits can arise as a solution to an optimal contracting problem and that nonprofits may be superior to for-profits when organizational output is hard to measure.
} 
Table 7. Differences in Wage Levels and Growth between the For-Profit and Nonprofit Sectors.

\begin{tabular}{|c|c|c|c|c|}
\hline Independent Variable & Starting Wage & Current Wage & $\begin{array}{c}\text { Within-Job } \\
\text { Wage Growth }\end{array}$ & $\begin{array}{c}\text { Inter-Job } \\
\text { Wage Growth }\end{array}$ \\
\hline For-Profit Status & $\begin{array}{c}0.038 \\
(0.065)\end{array}$ & $\begin{array}{c}0.059 \\
(0.061)\end{array}$ & $\begin{array}{c}-0.002 \\
(0.030)\end{array}$ & $\begin{array}{c}0.003 \\
(0.012)\end{array}$ \\
\hline \multicolumn{5}{|l|}{ Employee Characteristics } \\
\hline Performance & $\begin{array}{l}0.280 * * \\
(0.103)\end{array}$ & $\begin{array}{l}0.319 * * \\
(0.097)\end{array}$ & $\begin{array}{l}-0.179 * * \\
(0.086)\end{array}$ & $\begin{array}{c}0.033 \\
(0.026)\end{array}$ \\
\hline Typical Performance & $\begin{array}{c}-0.075 \\
(0.144)\end{array}$ & $\begin{array}{c}-0.010 \\
(0.139)\end{array}$ & $\begin{array}{c}-0.036 \\
(0.097)\end{array}$ & $\begin{array}{c}0.026 \\
(0.040)\end{array}$ \\
\hline High School Degree or More & $\begin{array}{l}0.119 * * \\
(0.032)\end{array}$ & $\begin{array}{l}0.120 * * \\
(0.030)\end{array}$ & $\begin{array}{c}0.016 \\
(0.020)\end{array}$ & $\begin{array}{c}0.010 \\
(0.011)\end{array}$ \\
\hline College Degree or More & $\begin{array}{l}0.194 * * \\
(0.054)\end{array}$ & $\begin{array}{l}0.193 * * \\
(0.053)\end{array}$ & $\begin{array}{c}0.042 \\
(0.029)\end{array}$ & $\begin{array}{c}0.006 \\
(0.015)\end{array}$ \\
\hline Tenure & $\begin{array}{c}0.304^{*} \\
(0.157)\end{array}$ & $\begin{array}{l}0.489 * * \\
(0.161)\end{array}$ & $\begin{array}{c}-0.042 \\
(0.081)\end{array}$ & $\begin{array}{c}0.107 * \\
(0.058)\end{array}$ \\
\hline Tenure Squared & $\begin{array}{c}-0.093 \\
(0.079)\end{array}$ & $\begin{array}{c}-0.197 * \\
(0.115)\end{array}$ & $\begin{array}{c}-0.022 \\
(0.040)\end{array}$ & $\begin{array}{c}-0.066 \\
(0.055)\end{array}$ \\
\hline \multicolumn{5}{|l|}{ Demographics } \\
\hline Age & $\begin{array}{l}6.093^{* *} \\
(0.877)\end{array}$ & $\begin{array}{l}6.363^{* *} \\
(0.940)\end{array}$ & $\begin{array}{c}-0.467 \\
(0.703)\end{array}$ & $\begin{array}{c}0.601 * \\
(0.327)\end{array}$ \\
\hline Age Squared & $\begin{array}{l}-7.550 * * \\
(1.190)\end{array}$ & $\begin{array}{l}-7.709 * * \\
(1.319)\end{array}$ & $\begin{array}{c}0.673 \\
(0.993)\end{array}$ & $\begin{array}{l}-0.677 \\
(0.453)\end{array}$ \\
\hline Male & $\begin{array}{l}0.141 * * \\
(0.028)\end{array}$ & $\begin{array}{l}0.138 * * \\
(0.028)\end{array}$ & $\begin{array}{c}0.018 \\
(0.022)\end{array}$ & $\begin{array}{c}-0.001 \\
(0.009)\end{array}$ \\
\hline White & $\begin{array}{l}0.133 * * \\
(0.027)\end{array}$ & $\begin{array}{l}0.111^{* *} \\
(0.027)\end{array}$ & $\begin{array}{c}0.012 \\
(0.018)\end{array}$ & $\begin{array}{c}-0.016^{*} \\
(0.009)\end{array}$ \\
\hline \multicolumn{5}{|l|}{ Firm Characteristics } \\
\hline Establishment Size & $\begin{array}{l}0.027 * * \\
(0.009)\end{array}$ & $\begin{array}{l}0.030 * * \\
(0.006)\end{array}$ & $\begin{array}{c}0.009 \\
(0.013)\end{array}$ & $\begin{array}{c}0.005 \\
(0.008)\end{array}$ \\
\hline Franchise & $\begin{array}{c}-0.053 \\
(0.041)\end{array}$ & $\begin{array}{c}-0.022 \\
(0.042)\end{array}$ & $\begin{array}{l}0.072 * * \\
(0.036)\end{array}$ & $\begin{array}{c}0.035 \\
(0.022)\end{array}$ \\
\hline Number of Sites & $\begin{array}{l}-0.064^{* * *} \\
(0.019)\end{array}$ & $\begin{array}{l}-0.059 * * \\
(0.015)\end{array}$ & $\begin{array}{c}0.042 \\
(0.031)\end{array}$ & $\begin{array}{c}0.009 \\
(0.007)\end{array}$ \\
\hline Union & $\begin{array}{l}0.137 * * \\
(0.054)\end{array}$ & $\begin{array}{l}0.107 * * \\
(0.053)\end{array}$ & $\begin{array}{c}0.003 \\
(0.037)\end{array}$ & $\begin{array}{c}-0.014 \\
(0.010)\end{array}$ \\
\hline Fraction of High-Skill Employees & $\begin{array}{l}0.298^{* *} \\
(0.048)\end{array}$ & $\begin{array}{l}0.297 * * \\
(0.047)\end{array}$ & $\begin{array}{l}-0.114 * * \\
(0.040)\end{array}$ & $\begin{array}{l}-0.013 \\
(0.018)\end{array}$ \\
\hline Temporary Workers & $\begin{array}{c}0.039 \\
(0.032)\end{array}$ & $\begin{array}{c}0.024 \\
(0.031)\end{array}$ & $\begin{array}{c}-0.031 \\
(0.022)\end{array}$ & $\begin{array}{c}-0.007 \\
(0.010)\end{array}$ \\
\hline Contract Workers & $\begin{array}{c}0.046 \\
(0.029)\end{array}$ & $\begin{array}{c}0.052 * \\
(0.029)\end{array}$ & $\begin{array}{c}0.008 \\
(0.021)\end{array}$ & $\begin{array}{c}-0.004 \\
(0.009)\end{array}$ \\
\hline
\end{tabular}

likely than nonprofits to have output-contingent compensation contracts, we note that bonuses (and other supplements) are sometimes based on things other than individual output, such as aggregate firm profitability or the achievement of safety milestones. However, the MCSUI also contains a more detailed breakdown of a number of different modes of output-contingent compensation, and some of these (for example, commissions and piece rates) are clearly based on output at the level of the individual worker.

As seen in Table 8, nonprofits were more than 11 percentage points less likely than 
Table 7. Continued.

\begin{tabular}{|c|c|c|c|c|}
\hline Independent Variable & Starting Wage & Current Wage & $\begin{array}{c}\text { Within-Job } \\
\text { Wage Growth }\end{array}$ & $\begin{array}{c}\text { Inter-Job } \\
\text { Wage Growth }\end{array}$ \\
\hline \multicolumn{5}{|l|}{ Industry Controls } \\
\hline Construction and Mining & $\begin{array}{c}0.030 \\
(0.056)\end{array}$ & $\begin{array}{l}0.093 * * \\
(0.047)\end{array}$ & $\begin{array}{c}0.003 \\
(0.051)\end{array}$ & $\begin{array}{c}0.052 * \\
(0.031)\end{array}$ \\
\hline Manufacturing & $\begin{array}{c}0.017 \\
(0.039)\end{array}$ & $\begin{array}{c}0.051 \\
(0.038)\end{array}$ & $\begin{array}{c}0.005 \\
(0.029)\end{array}$ & $\begin{array}{l}0.033^{* *} * \\
(0.013)\end{array}$ \\
\hline Transportation & $\begin{array}{c}0.038 \\
(0.042)\end{array}$ & $\begin{array}{c}0.025 \\
(0.041)\end{array}$ & $\begin{array}{c}0.024 \\
(0.040)\end{array}$ & $\begin{array}{c}0.002 \\
(0.018)\end{array}$ \\
\hline Wholesale Trade & $\begin{array}{c}-0.074 \\
(0.054)\end{array}$ & $\begin{array}{c}-0.078 * \\
(0.046)\end{array}$ & $\begin{array}{c}-0.015 \\
(0.041)\end{array}$ & $\begin{array}{c}0.034 \\
(0.026)\end{array}$ \\
\hline Retail Trade & $\begin{array}{c}-0.171 * * \\
(0.039)\end{array}$ & $\begin{array}{c}-0.153^{* *} \\
(0.043)\end{array}$ & $\begin{array}{c}-0.001 \\
(0.034)\end{array}$ & $\begin{array}{c}0.019 \\
(0.020)\end{array}$ \\
\hline Finance & $\begin{array}{c}0.029 \\
(0.042)\end{array}$ & $\begin{array}{c}0.067 \\
(0.042)\end{array}$ & $\begin{array}{c}0.024 \\
(0.039)\end{array}$ & $\begin{array}{l}0.042^{* * *} \\
(0.021)\end{array}$ \\
\hline Public Administration & $\begin{array}{c}0.083 \\
(0.083)\end{array}$ & $\begin{array}{c}0.130 \\
(0.080)\end{array}$ & $\begin{array}{c}-0.014 \\
(0.056)\end{array}$ & $\begin{array}{c}0.045 \\
(0.031)\end{array}$ \\
\hline \multicolumn{5}{|l|}{ Occupation Controls } \\
\hline Professionals & $\begin{array}{l}0.309 * * \\
(0.060)\end{array}$ & $\begin{array}{l}0.345^{* *} \\
(0.059)\end{array}$ & $\begin{array}{c}0.058 \\
(0.035)\end{array}$ & $\begin{array}{c}0.017 \\
(0.024)\end{array}$ \\
\hline Sales & $\begin{array}{l}0.127 * * \\
(0.031)\end{array}$ & $\begin{array}{l}0.137 * * \\
(0.031)\end{array}$ & $\begin{array}{l}0.063 * * \\
(0.024)\end{array}$ & $\begin{array}{c}0.011 \\
(0.012)\end{array}$ \\
\hline Services & $\begin{array}{c}-0.095^{* *} \\
(0.048)\end{array}$ & $\begin{array}{c}-0.084 * \\
(0.048)\end{array}$ & $\begin{array}{c}0.001 \\
(0.029)\end{array}$ & $\begin{array}{c}0.003 \\
(0.015)\end{array}$ \\
\hline \multicolumn{5}{|l|}{ Additional Controls } \\
\hline Promotion Occurred & & & & $\begin{array}{l}0.101^{* *} \\
(0.046)\end{array}$ \\
\hline $\begin{array}{l}\text { Interaction between Promotion } \\
\text { and For-Profit Status }\end{array}$ & & & & $\begin{array}{l}-0.027 \\
(0.052)\end{array}$ \\
\hline Constant & $\begin{array}{c}0.324 * \\
(0.177)\end{array}$ & $\begin{array}{c}0.181 \\
(0.183)\end{array}$ & $\begin{array}{l}0.499 * * \\
(0.127)\end{array}$ & $\begin{array}{l}-0.151 * * \\
(0.072)\end{array}$ \\
\hline Number of Observations & 1,391 & 1,372 & 1,262 & 1,335 \\
\hline
\end{tabular}

Notes: Within-job wage growth is the difference between the highest attainable wage in the position and the starting wage. Inter-job wage growth is the difference between the expected wage if promoted and the current wage. Standard errors are in parentheses.

*Statistically significant at the .10 level; **at the .05 level.

for-profits to pay commissions on sales, and more than 30 percentage points less likely to pay bonuses. Furthermore, while only about $4 \%$ of for-profits reported having piece-rate compensation, virtually no nonprofits used piece rates. While about $30 \%$ of for-profits used profit sharing, only $1.3 \%$ of nonprofits reported doing so. ${ }^{7}$ The last row in the table

${ }^{7}$ While the definition of a nonprofit implies that this fraction should be zero, we suspect that affirmative re- reports conditional differences in means controlling for firm characteristics and industry, estimated from probit equations. These

sponses to this question reflect different interpretations of "profit-sharing" on the part of nonprofit employers. For example, employers basing compensation on the ratio of program service expense to total expense might well have interpreted this as profit-sharing, since this was the only organizational-level output-based pay choice offered in the survey. 
Table 8. Differences in Output-Based Pay by For-Profit Status.

\begin{tabular}{llcccc}
\hline For-Profit Status & Tips? & Commission on Sales? & Piece Rates? & Bonuses? & Profit Sharing? \\
\hline For-Profits & 0.058 & 0.125 & 0.038 & 0.486 & 0.297 \\
Nonprofits & 0.011 & 0.014 & 0.006 & 0.180 & 0.013 \\
Difference in Means (unconditional) & $\mathbf{0 . 0 4 7} * *$ & $\mathbf{0 . 1 1 2} * *$ & $\mathbf{0 . 0 3 2} * *$ & $\mathbf{0 . 3 0 7} * *$ & $\mathbf{0 . 2 8 4} * *$ \\
Difference in Means (conditional) & $\mathbf{0 . 0 1 3} * *$ & $\mathbf{0 . 0 3 6} * *$ & $\mathbf{0 . 0 0 7}$ & $\mathbf{0 . 2 8 9} * *$ & $\mathbf{0 . 2 8 0} * *$ \\
\hline
\end{tabular}

Notes: The last row reports estimates from a probit equation controlling for firm characteristics and industry. These cell entries are the change in the predicted probability of the dependent variable when for-profit status increases from zero to one, evaluating other covariates at their means.

**Statistically significant at the .05 level.

cell entries are the change in the predicted probability of the dependent variable when for-profit status increases from zero to one, evaluating other covariates at their means. In summary, the empirical evidence here, in conjunction with the evidence from the previous literature, indicates that output-based compensation contracts (based either on organization-wide or individual-level output measures) were less prevalent in nonprofits than in for-profits.

\section{Intrinsic Motivation and the Role of Promotions in Organizations}

We now propose a theory that potentially explains the broad pattern of evidence we have documented in the previous two sections. Our proposed theory brings together two ideas from distinct theoretical literatures. First is the idea that workers in nonprofits are intrinsically motivated by the organizational mission, so that incentives are created automatically when jobs reside in nonprofit organizations. Second is the dual role of promotions in firms, both in creating incentives and in assigning workers to jobs. A difficult question posed in Baker, Jensen, and Murphy (1988) is why firms rely on promotions both to create incentives and to assign workers to jobs, given that the firm typically faces a tradeoff between these objectives, achieving neither perfectly. It would seem to make more sense to use promotions for job assignment, relying on some other vehicle (such as bonuses) to create incentives. This has been dubbed the "Baker-Jensen-Murphy Puzzle" in Gibbons and Waldman (1999). Our theory is that the prominence of intrinsic motivation in nonprofits enables nonprofit employers to de-emphasize the incentive function of promotions and concentrate more on using promotions to achieve optimal job assignments. In contrast, for-profit employers must rely heavily on promotions both for incentives and for job assignment, presumably achieving neither goal perfectly. That is, the tradeoff in the Baker-Jensen-Murphy Puzzle is confronted by for-profits to a greater extent than by nonprofits.

Intrinsically motivated effort is defined as effort a worker exerts in the absence of external rewards. Theories of intrinsic motivation have their roots in the organizational psychology and management literatures. The main source of intrinsic motivation is the design of jobs, meaning the particular characteristics or attributes of jobs. Theories of motivational job design such as the Job Characteristics Model proposed by Hackman and Oldham (1980) focus on how certain job characteristics that are chosen by employers affect worker motivation. One of the five core job characteristics in that model is "task significance," or the extent to which a job affects the lives of others. Greater task significance increases the degree of experienced meaningfulness of one's work, which ultimately yields higher worker performance.

The mission of the organization can also serve as a source of intrinsic motivation, if it fits a worker's value system (in which case we refer to it as a "positive social mission"). It is such mission-driven intrinsic motivation that is at the heart of our theory. One interpretation is that intrinsic motivation deriving from the organizational mission is distinct from the intrinsic motivation deriv- 
ing from job characteristics that we discussed in the previous paragraph. An alternative interpretation, and the one we favor, is that a positive social mission itself shapes core job characteristics, so that the resulting intrinsic motivation may still be thought of as arising from job characteristics. For example, in the Job Characteristics Model, a positive social mission would naturally increase the "task significance" of a job. Thus, even when tasks are identical in a given job in two different organizations, if one organization has a positive social mission and the other does not, task significance (and thereby intrinsic motivation) should be higher in the organization with the positive mission. In this sense, intrinsic motivation driven by the mission and intrinsic motivation driven by job characteristics are one and the same.

The key assumption of our theory is that a positive social mission (and thereby mission-driven intrinsic motivation) is higher, on average, in nonprofits than in for-profits. While a positive social mission is certainly possible in for-profits (for example, research scientists in drug companies might be passionate about the perceived social contributions of their occupations and employers), it is assumed to be more likely in nonprofits. We also acknowledge that the job characteristics associated with high intrinsic motivation are present in for-profitjobs as well as in nonprofit jobs. Our theory does not require that forprofit jobs be devoid of intrinsic motivation or that workers in for-profit jobs have no passion for the firm's mission. We only require that, on average, such intrinsic motivation is greater in nonprofit jobs than in for-profit jobs. This assumption seems reasonable to us and consistent with the previous literature on nonprofits.

The idea is also in harmony with the theory of "labor donations" put forth in Preston (1989); with the empirical literature on wage differentials between the two sectors, which argues that nonprofit status represents a nonpecuniary job characteristic that some workers value positively; with survey evidence on worker attitudes (Rawls, Ullrich, and Nelson 1975); and with a recent theoretical literature in economics arguing that in the presence of intrinsic motivation, principals can economize on incentives (Besley and Ghatak 2005; Benabou and Tirole 2003; Francois 2000). For example, Besley and Ghatak (2005) proposed a contract-theoretical approach to the provision of collective goods, drawing a distinction between "mission-oriented" nonprofit organizations and "profit-oriented" conventional firms. They argued that agents and principals in organizations that provide collective goods (hospitals, schools, and universities) care about nonmonetary aspects of their activities; such individuals are referred to as "motivated agents." The main insights to emerge from their analysis are that intrinsic motivation can substitute for explicit incentives in the organization, and that matching principals and agents on "mission-preferences" increases efficiency and makes high-powered incentives less necessary in such organizations. Our incentive-based rationale for promotion differences between the two sectors is consistent with these themes.

If our theory is correct, we would expect to find evidence consistent with promotions creating weaker incentives in nonprofits than in for-profits, since nonprofit employers rely on promotions relatively more for job assignment than for incentives. Three conditions must generally hold for promotions to create strong incentives: promotions must be accompanied by wage increases, workers must believe a promotion is attainable within a reasonable length of time, and promotions must be based on worker performance in the prepromotion job. ${ }^{8}$ We have seen that the first condition is satisfied in both the nonprofits and the for-profits we examined, since promotions were accompanied by wage increases of comparable magnitudes in the two sectors. Regarding the second condition, we expect

\footnotetext{
${ }^{8} \mathrm{~A}$ wage increase is actually not necessary for incentives as long as there are other non-pecuniary benefits associated with promotion that the worker finds attractive (such as tenure in the case of a promotion from assistant to associate professor). Nonetheless, in most contexts (in both for-profits and nonprofits) sizable wage increases typically accompany promotions, and it seems a safe assumption that these increases contribute significantly to the appeal of a promotion from the worker's perspective.
} 
that workers' beliefs about the likelihood of their being promoted within some given time frame will be shaped by the frequency with which promotions occur in their organizations. If promotions are rare events, workers will believe that their promotion prospects in the foreseeable future are poor, and this will depress incentives. In contrast, the job assignment function of promotions does not require that they occur frequently; one can imagine production settings in which optimal job assignment is achieved and remains static for quite some time, with no need for any job reassignments through promotions. Our main empirical finding is that promotions occurred less frequently on average in the nonprofit sector, suggesting that the second condition was not satisfied as strongly in the nonprofit sector as in the for-profit sector. Our empirical evidence also indicates that the third condition was not satisfied as strongly in the nonprofit sector as in the forprofit sector. Thus, we interpret the results as consistent with the incentive function of promotions being weaker in nonprofits than in for-profits.

To further investigate the idea that nonprofits rely less on promotions to create incentives than do for-profits, we use the structural model of promotion tournaments proposed in DeVaro (2006). In a standard tournament model of the type first introduced by Lazear and Rosen (1981), promotions are used as a means for creating incentives. Workers at a given level in an organization compete for promotion to a higher level, and the best performer wins the promotion (and the associated higher wage). Thus, promotions are determined by relative performance rather than absolute performance. Furthermore, the employer chooses the wage spread between the higher-level and lower-level jobs so as to elicit the optimal worker effort in the lower-level job. DeVaro (2006), presenting a structural analysis to empirically test the promotion tournament model using a subsample of 632 skilled workers from the MCSUI, showed that tournament theory yields predictions on the signs of three key parameters. In that analysis, all three estimated parameters had the predicted signs and were statistically significant. If our incentives-based theory in the present analysis is correct, meaning that for-profits rely on promotion tournaments to create worker incentives more than do nonprofits, empirical support for the three predictions in DeVaro (2006) should be even stronger if we estimate the structural model on the subsample of 551 for-profits (out of the 632). This is in fact the case. ${ }^{9}$

Furthermore, if our theory is correct, we would also expect nonprofits to rely less heavily than for-profits on output-based incentive contracts. This is for the same reason we expect nonprofits to rely less heavily on promotion-based incentives, namely that the intrinsic motivation deriving from nonprofit jobs allows the employer to substitute intrinsic motivation for the explicit incentives created through output-based contracts. Our empirical results reported in Table 8 are consistent with this prediction: nonprofits clearly relied on output-based incentive contracts less than for-profits did. In a related discussion, Frey (1997) noted that under certain conditions intrinsic motivation can be "crowded out" by external rewards like pay-for-performance, arguing that this could be the reason why managers of nonprofits receive a smaller share of their compensation in bonuses than do managers in for-profits.

Given that nonprofits appear to rely less on promotion-based incentives and on output-based compensation than do for-profits, and given that prospects for within-job wage growth (and the wage increases attached to promotion) are no higher in nonprofits than in for-profits, it is natural to ask whether incentives suffer in nonprofits and whether workers ultimately have lower average performance in nonprofits. This appears not to have been the case in the establishments we studied, since the average worker performance score in nonprofits was 80.7 , versus

${ }^{9}$ Using the notation from DeVaro (2006), the tournament promotion model predicts the following signs for the three key parameters: $\alpha>0, \sigma_{12}<0$, and $\gamma_{3}>0$. The estimates in DeVaro (2006) using all 632 observations are as follows: $\alpha=0.591(Z=1.81), \sigma_{12}$ $=-0.091(Z=1.72), \gamma_{3}=1.496(Z=2.89)$. Dropping the 81 nonprofits from this sample and re-estimating the model yields $\alpha=0.709(\mathrm{Z}=1.98), \sigma_{12}=-0.118(\mathrm{Z}$ $=1.75), \gamma_{3}=1.633(\mathrm{Z}=2.85)$. 
77.8 in for-profits. ${ }^{10}$ This difference favoring nonprofit worker performance, though small in magnitude, attains statistical significance at the $5 \%$ level unless controls for worker and firm characteristics are included (in which case the statistical significance is lost). If average performance levels are the same in for-profits and nonprofits, it would appear that nonprofits have some other means of creating worker incentives. Our conjecture is that workers in nonprofits are intrinsically more motivated than for-profit workers, by virtue of their interest in the organizational mission of the nonprofit, so that effort is more costly to workers in for-profits than in nonprofits.

If our theory is correct, we would also expect the difference in intrinsic motivation (and thereby in promotion probabilities) between the two sectors to be most pronounced for high-skilled jobs. In addition to our assumption that a positive social mission is more likely in nonprofits than for-profits, this prediction rests on two very plausible further assumptions. First is the assumption that the work of high-skilled workers in the higher levels of organizations tends to be more tightly linked to the organizational mission (whether or not it is positive) than the work of low-skilled workers. Second is the assumption that when the mission is positive, mission-driven intrinsic motivation increases as a worker's tasks become more tightly linked to the organizational mission, whereas when the mission is not positive, no mission-based intrinsic motivation results regardless of how tightly the mission is linked to tasks.

The intuition is that the work in lowskilled jobs, such as those of janitors, is so

\footnotetext{
${ }^{10}$ Since incentives are not the only determinants of worker performance, a selection effect might be working in the opposite direction. That is, it is possible that nonprofit employers draw from a higher-ability distribution of workers than do for-profit firms, so that even if nonprofits offer weaker incentives than do for-profits, this might not be detectable by simple comparisons of average performance. A further reason for caution in interpreting this result is that performance expectations on the part of respondent managers might differ systematically between the nonprofit and for-profit sectors. The performance measures are within-establishment scales.
}

far removed from the organizational mission that a positive social mission will not create much mission-driven intrinsic motivation. Thus, if our theory is correct, there should not be much difference between nonprofits and for-profits in mission-driven intrinsic motivation (and thereby promotion rates) if we consider only very low-skilled jobs. In contrast, the high-skilled workers who tend to populate the higher levels of a job hierarchy will have tasks more closely tied to the organizational mission. Thus, given our assumption that a positive social mission is more likely in nonprofits than in for-profits, for such workers we should see a large intersectoral difference in mission-driven intrinsic motivation (and consequently promotion rates). That is, promotions are less likely to be needed by the nonprofit employer as incentive-creation devices for an already intrinsically motivated staff of highly skilled professional workers. Our empirical results are consistent with this prediction.

A similar argument was made by Preston (1989:443), who claimed that the further removed the worker is from the generation of social benefits, the less likely he will be to "donate" his labor at a reduced wage. Therefore, a negative nonprofit wage differential is most likely to occur in managerial and professional occupations. Preston found some empirical evidence supporting this hypothesis.

As an overall comment on the compatibility of our proposed theory with our empirical findings, we are struck by how neatly the various empirical results fit together to compose a coherent picture. In our view, a useful criterion for evaluating the relative merits of alternative possible explanations for these results is the extent to which each can explain broad patterns of related empirical evidence, as opposed to isolated single facts such as our main result that promotions were less likely in nonprofits. While our incentives-based explanation is only a conjecture, it is worth considering some of the broader implications suggested by it. In particular, if our explanation is correct, then it should have implications for the choice of organizational structure in nonprofits versus for-profits. In particular, the fact that nonprofits may be 
flatter organizations than for-profits may be understood within our framework. The organizational benefits to be had from a flatter versus a more hierarchical organizational structure might be easier to realize in nonprofits, if promotions can be used mostly for optimal job assignment and are not as important for creating incentives. We emphasize, however, that while these considerations may play a role in determining the firm's choice of organizational structure, the roles of environment and the production technology should be at least as important.

\section{Conclusion}

While previous literature has focused heavily on differences in compensation between the nonprofit and for-profit sectors, we have focused on differences in the probability of promotion. To summarize the results of our analysis of data from a 1992-95 survey of employers, (1) promotions were less likely in nonprofits than in for-profits, and this difference does not appear to have been due to differences in establishment-wide turnover rates between the two sectors, to other observed characteristics of workers or firms, to anomalous features of one of the occupations studied, or to the fact that nonprofits were more likely than for-profits to report that "no promotion [was] possible" out of a given job; (2) the observed difference in promotion rates between the nonprofit and for-profit sectors was more pronounced for high-skilled than for low-skilled workers; (3) nonprofits were more likely than for-profits to have formal procedures for internal hiring; (4) starting wages, current wages, wage increases associated with promotion, and the potential for within-job wage growth were similar in the two sectors; (5) nonprofits appear to have been less likely than for-profits to use promotions as incentive mechanisms, as indicated by evidence that the relationship between performance and promotions was weaker in nonprofits; (6) nonprofits were less likely than for-profits to use output-contingent incentive contracts; and (7) even though nonprofits used fewer direct incentive mechanisms to motivate workers than for-profits did, average worker performance was similar in the two sectors.

We conclude with some comments about how this work could be extended with the development of new data sets. As this is the first study to identify the intriguing result that promotions are less likely in nonprofit organizations, and since that result is based on only one data set, there is a clear need for future work that investigates the same research question using complementary information from other data sources. Beyond testing the main result, there are a number of issues that might be fruitfully addressed with new data sets.

First, it would be interesting to conduct our analyses within particular narrowly defined industries in which nonprofits and for-profits operate side by side. The MCSUI sample is not large enough to permit such analyses; the best we could do was to present some analysis within the service sector. But a detailed comparison of promotions in for-profits and nonprofits that operate in the same setting (for example, hospitals) would be enlightening and would increase our confidence that a promotion in a nonprofit means the same thing as a promotion in a for-profit.

Second, it would be useful to compare rates of internal versus external hiring in the for-profit and nonprofit sectors, since questions about promotions are closely tied to questions about internal hiring rates. The MCSUI only allowed us to make an indirect statement about this, namely that nonprofits were more likely than for-profits to have formal procedures for hiring internally.

Third, a more complete analysis of potential differences in turnover rates between the two sectors would be desirable. We found that our main result was unaffected by differences between the two sectors in establishment-wide turnover rates. However, ideally we would want to compare turnover rates at different levels of the hierarchy rather than establishment-wide, and while this was not possible with the MCSUI (since each establishment's job hierarchy is not observed), it might be with future data.

Finally, longitudinal data that follow the same workers over a longer period of time 
would provide a clearer picture of how the evolution of careers in organizations differs between the nonprofit and for-profit sectors. While the retrospective information on promotions contained in the MCSUI is useful, the sample construction based on the most recently hired worker is obviously limiting for analyses of promotions. We observe at most one promotion event for each worker. In the event that the most recently hired worker was promoted more than once since the starting date, this would not be detectable in the data (though such events should be rare). More important, if a promotion is observed for a given worker we have no information on what happened subsequently. This precludes the exploration of some interesting questions, such as whether promotion fast tracks exist and differ between the two sectors and how patterns of wage growth are affected by successive promotions. Data that track worker histories over longer time periods within the organization could shed light on these issues. The challenge is finding such data that span multiple organizations in both the for-profit and nonprofit sectors.

APPENDIX

Variables

\begin{tabular}{|c|c|}
\hline Variable & Defined as \\
\hline \multicolumn{2}{|l|}{ Dependent Variables } \\
\hline \multicolumn{2}{|l|}{ Promotion Variables } \\
\hline Promotions & $=1$ if promotion has occurred by the survey date; 0 otherwise \\
\hline Expected Promotions & $=1$ if promotion is expected in the next 5 years; 0 otherwise \\
\hline \multicolumn{2}{|l|}{ Internal Hiring Variable } \\
\hline $\begin{array}{l}\text { Formal Procedures for } \\
\text { Internal }\end{array}$ & $\begin{aligned}= & 1 \text { if the establishment has formal procedures for posting internal job } \\
& \text { openings and soliciting applications }\end{aligned}$ \\
\hline Hiring & for filling them; 0 otherwise \\
\hline
\end{tabular}

Variables Measuring the Basis of Promotion

Merit or Job Performance

Seniority

Affirmative Action

Wage Variables $^{\mathrm{a}}$

Starting Wage

Current Wage

Within Job Wage Growth

Inter-Job Wage Growth

Output-Based Pay Variables

Tips

Commission on Sales
$=3$ if promotions are based "mostly" on merit; 2 if promotions are based "somewhat" on merit; 1 if promotions are based "not at all" on merit

$=3$ if promotions are based "mostly" on seniority; 2 if promotions are based "somewhat" on seniority; 1 if promotions are based "not at all" on seniority

$=3$ if promotions are based "mostly" on affirmative action; 2 if promotions are based "somewhat" on affirmative action; 1 if promotions are based "not at all" on affirmative action

$=$ the $\log$ of the most recently hired worker's hourly starting wage at the time of the survey

$=$ the log of the most recently hired worker's hourly current wage at the time of the survey

$=$ the difference between the log of the highest wage or salary that any employee in the position (into which the most recently hired worker was hired) could expect to be paid without promotion and the log of the starting wage

$=$ the percentage wage change from the starting date to the survey date

$=1$ if employees in the position of the most recently hired worker receive tips, in addition to a wage or salary; 0 otherwise

$=1$ if employees in the position of the most recently hired worker receive a commission on sales, in addition to a wage or salary; 0 otherwise 
APPENDIX

Continued.

Variable Defined as

Piece Rates

Bonuses

Profit Sharing

\section{Independent Variables}

Firm Characteristics

For-Profit Status

Franchise

Number of Sites

Establishment Size

Union

Fraction of High Skill Employees

Temporary Workers

Contract Workers

Hiring Rate ${ }^{b}$

Separation Rate

Net Change in Employees

Industry ${ }^{\mathrm{C}}$

Construction and Mining

Manufacturing

Transportation

Wholesale Trade

Retail Trade

Finance

Services

Public Administration

Employee Characteristics

Performance

Typical Performance

High School Degree or More College Degree or More

Tenure
$=1$ if there are piece rates for employees in the position of the most recently hired worker, in addition to a wage or salary; 0 otherwise

$=1$ if there are bonuses for employees in the position of the most recently hired worker, in addition to a wage or salary; 0 otherwise

$=1$ if there is profit sharing for employees in the position of the most recently hired worker, in addition to a wage or salary; 0 otherwise

$=1$ if establishment is for-profit; 0 otherwise

$=1$ if establishment is a franchise; 0 otherwise

$=$ number of sites at which the establishment operates

$=$ number of workers in establishment

$=$ percentage of non-professional and non-managerial employees who are covered by a collective bargaining agreement

$=$ share of employees with a high school degree or more

$=1$ if establishment has temporary employees; 0 otherwise

$=1$ if establishment has contract employees; 0 otherwise

$=($ number of new hires since start of 1992) / (establishment size $\times$ months $)$

$=($ discharges + quits + layoffs - recalls $) /($ establishment size $\times$ months $)$

$=($ net change since start of 1992) / (establishment size $\times$ months $)$

$=1$ if establishment is in the construction or mining industries; 0 otherwise

$=1$ if establishment is in the manufacturing industry; 0 otherwise

$=1$ if establishment is in the transportation industry; 0 otherwise

$=1$ if establishment is in the wholesale trade industry; 0 otherwise

$=1$ if establishment is in the retail trade industry; 0 otherwise

$=1$ if establishment is in the finance industry; 0 otherwise

$=1$ if establishment is in the services industry; 0 otherwise

$=1$ if establishment is in the public administration industry; 0 otherwise

$=$ most recently hired worker's performance level on scale of 0 to 100 (where 100 is high and 50 is average)

$=$ performance level of a "typical" worker in the position into which the most recently hired worker was hired, on scale of 0 to 100 (where 100 is high and 50 is average)

$=1$ if the most recently hired worker has a high school degree; 0 otherwise

$=1$ if the most recently hired worker has a college degree or more; 0 otherwise

$=$ number of months the most recently hired worker has been with the establishment 
APPENDIX

Continued.

\begin{tabular}{|c|c|}
\hline Variable & Defined as \\
\hline \multicolumn{2}{|l|}{ Demographics } \\
\hline Age & $=$ age of the most recently hired worker \\
\hline Male & $=1$ if the most recently hired worker is a male; 0 otherwise \\
\hline White & $=1$ if the most recently hired worker is white; 0 otherwise \\
\hline Black & $=1$ if the most recently hired worker is black; 0 otherwise \\
\hline Hispanic & $=1$ if the most recently hired worker is Hispanic; 0 otherwise \\
\hline Other Non-White & $\begin{array}{l}=1 \text { if the most recently hired worker is another non-white race or ethnicity; } \\
0 \text { otherwise }\end{array}$ \\
\hline \multicolumn{2}{|l|}{ Job Characteristics } \\
\hline Talk & $\begin{aligned}= & 1 \text { if position requires talking face-to-face with customers or clients on a } \\
& \text { daily basis; } 0 \text { otherwise }\end{aligned}$ \\
\hline Phone & $\begin{array}{l}=1 \text { if position requires talking over the phone with customers or clients on a } \\
\text { daily basis; } 0 \text { otherwise }\end{array}$ \\
\hline Math & $\begin{array}{l}=1 \text { if position requires doing arithmetic or other computations on a daily } \\
\text { basis; } 0 \text { otherwise }\end{array}$ \\
\hline Compute & $=1$ if position requires working with a computer on a daily basis; 0 otherwise \\
\hline Read & $\begin{array}{l}=1 \text { if position requires reading instructions at least one paragraph long on a } \\
\text { daily basis; } 0 \text { otherwise }\end{array}$ \\
\hline Write & $\begin{array}{l}=1 \text { if position requires writing paragraphs or memos on a daily basis; } \\
0 \text { otherwise }\end{array}$ \\
\hline $\begin{array}{l}\text { Position Requires College } \\
\text { Degree }\end{array}$ & $=1$ if position requires a college degree; 0 otherwise \\
\hline \multicolumn{2}{|l|}{ Occupation Controls ${ }^{\mathrm{c}}$} \\
\hline Professionals & $\begin{array}{l}=1 \text { if the most recently hired worker's occupation is an administrative, } \\
\text { engineering, scientific, teaching, and related occupation, including } \\
\text { creative art; } 0 \text { otherwise }\end{array}$ \\
\hline Sales & $\begin{array}{l}=1 \text { if the most recently hired worker's occupation is a technical, clerical, } \\
\text { sales, and related occupation, or precision production, craft and repair; } \\
0 \text { otherwise }\end{array}$ \\
\hline Services & $\begin{array}{l}=1 \text { if the most recently hired worker's occupation is a service occupation, } \\
\text { including military occupations; } 0 \text { otherwise }\end{array}$ \\
\hline Low-Skilled Laborers & $\begin{array}{l}=1 \text { if the most recently hired worker is an operator, fabricator, or laborer; } \\
0 \text { otherwise }\end{array}$ \\
\hline
\end{tabular}

${ }^{a}$ The reported time frame for all MCSUI wage questions was either hourly, weekly, monthly, or annually, and we converted all responses to hourly wages measured in 1990 dollars, deflated using the CPI-UX.

'The variable "months" is the number of months that elapsed between the start of 1992 and the survey date (which ranges from June 8, 1992, to March 15, 1995), using the day of the month to compute fractional months. For a small subset of observations collected by Kirschenman, Moss, and Tilly, the employer was asked about the number of new hires since the start of 1993 rather than 1992. Since the actual interview dates were not recorded for these observations, we set these survey dates to March 15, 1995, the midpoint of the data collection period for these observations.

'Based on 1980 SOC codes. 


\section{REFERENCES}

Baker, George P. 1992. "Incentive Contracts and Performance Measurement." Journal of Political Economy, Vol. 100, No. 3 (June), pp. 598-614.

Baker, George, M. C. Jensen, and Kevin J. Murphy. 1988. "Compensation and Incentives: Practice versus Theory." Journal of Finance, Vol. 43, No. 3 (July), pp. 593-616.

Benabou, Roland, and Jean Tirole. 2003. "Intrinsic and Extrinsic Motivation." Review of Economic Studies, Vol. 70, No. 3 (July), pp. 489-520.

Bertrand, Marianne, Kevin F. Hallock, and Richard Arnould. 2005. "Does Managed Care Change the Management of Nonprofit Hospitals? Evidence from the Executive Labor Market." Industrial and Labor Relations Review, Vol. 58, No. 3 (April), pp. 494-514.

Besley, Timothy, and Maitreesh Ghatak. 2005. "Competition and Incentives with Motivated Agents." American Economic Review, Vol. 95, No. 3 (June), pp. 616-36.

Bureau of Labor Statistics. 2002. "Volunteering in the United States." Press release, December 18.

Cleverley, William O., and Robert P. Mullen. 1982. "Management Incentive Systems and Economic Performance in Health Care Organizations." Health Care Management Review, Vol. 7, No. 1 (Winter), pp. 7-14.

DeVaro, Jed. 2005. "Employer Recruitment Strategies and the Labor Market Outcomes of New Hires." Economic Inquiry, Vol. 43, No. 2 (April), pp. 263-82.

. 2006. "Internal Promotion Competitions in Firms." RAND Journal of Economics, Vol. 27, No. 3.

Easley, David, and Maureen O'Hara. 1983. "The Economic Role of the Nonprofit Firm." Bell Journal of Economics, Vol. 14, No. 2 (Autumn), pp. 531-38.

Francois, Patrick. 2000. "Public Service Motivation as an Argument for Government Provision." Journal of Public Economics, Vol. 78, No. 3, pp. 275-99.

Frey, Bruno S. 1997. "On the Relationship between Intrinsic and Extrinsic Work Motivation." International Journal of Industrial Organization, Vol. 15, pp. 427-39.

Gerhart, Barry, and George Milkovich. 1989. "Salaries, Salary Growth, and Promotions of Men and Women in a Large Private Firm." In R. Michael, H. Hartmann, and B. O'Farrell, eds., Pay Equity: Empirical Inquiries. Washington, D.C.: National Academy Press, pp. 23-48.

Gibbons, Robert, and Michael Waldman. 1999. "Careers in Organizations: Theory and Evidence." In Orley Ashenfelter and David Card, eds., Handbook of Labor Economics, Vol. 3B, pp. 2373-2437. Amsterdam: Elsevier.

Goddeeris, John H. 1988. "Compensating Differentials and Self-Selection: An Application to Lawyers." Journal of Political Economy, Vol. 96, No. 2 (April), pp. 411-28.

Hackman, Richard J., and Greg R. Oldham. 1980. Work Redesign. Boston: Addison-Wesley.

Hallock, Kevin F. 2000. "Compensation in Nonprofit Organizations." Research in Personnel and Human Resources Management, Vol. 19, pp. 243-94.

Hansmann, Henry B. 1980. "The Role of Nonprofit Enterprise." Yale Law Journal, Vol. 89, No. 5 (April), pp. 835-901.
1996. The Ownership of Enterprise. Cambridge: Harvard University Press.

Holzer, Harry. 1996. What Employers Want: Job Prospects for Less-Educated Workers. New York: Russell Sage Foundation.

Holzer, Harry, Joleen Kirschenman, Philip Moss, and Chris Tilly. 1998. Multi-City Study of Urban Inequality, 1992-1994 [Atlanta, Boston, Detroit, and Los Angeles] [Telephone Survey Data] [Computer file]. ICPSR version. Atlanta: Mathematica; Boston: University of Massachusetts, Survey Research Laboratory; Ann Arbor: University of Michigan, Detroit Area Study and Institute for Social Research, Survey Research Center; Los Angeles: University of California, Survey Research Program [producers]. Inter-university Consortium for Political and Social Research [distributor].

Lazear, Edward P. 1992. "The Job as a Concept." In William J. Bruns, Jr., ed., Performance Measurement, Evaluations, and Incentives, pp. 335-41. Boston: Harvard Business School Press.

Lazear, Edward P., and Sherwin Rosen. 1981. "RankOrder Tournaments as Optimum Labor Contracts." Journal of Political Economy, Vol. 89, No. 1 (February), pp. 841-64.

Leete, Laura. 2001. "Whither the Nonprofit Wage Differential? Estimates from the 1990 Census." Journal of Labor Economics, Vol. 19, No. 1 (January), pp. 136-70.

McCue, Kristin. 1996. "Promotions and Wage Growth." Journal of Labor Economics, Vol. 14, No. 2 (April), pp. 175-209.

Mocan, H. Naci, and Erdal Tekin. 2003. "Nonprofit Sector and Part-Time Work: An Analysis of EmployerEmployee Matched Data on Child Care Workers." Review of Economics and Statistics, Vol. 85, No. 1 (February), pp. 38-50.

Oster, Sharon. 1996. "Nonprofit Organizations and Their Local Affiliates: A Study in Organizational Forms." Journal of Economic Behavior and Organization, Vol. 30, No. 1, pp. 83-95.

Preston, Anne. 1989. "The Nonprofit Worker in a ForProfit World.” Journal of Labor Economics, Vol. 7, No. 4 (October), pp. 438-63.

Rawls, James R., Robert A. Ullrich, and Oscar Tivis Nelson, Jr. 1975. "A Comparison of Managers Entering or Reentering the Profit and Nonprofit Sectors." Academy of Management Journal, Vol. 18, No. 3 (September), pp. 616-23.

Roomkin, Myron J., and Burton A. Weisbrod. 1999. "Managerial Compensation and Incentive in For-Profit and Nonprofit Hospitals." Journal of Law, Economics, and Organization, Vol. 15, No. 3, pp. 750-81.

Salamon, Lester M., and S. Wojciech Sokolowski. 2005. "Nonprofit Organizations: New Insights from QCEW Data." Monthly Labor Review, Vol. 128, No. 9 (September), pp. 19-26.

Weisbrod, Burton. 1983. "Nonprofit and Proprietary Sector Behavior: Wage Differentials among Lawyers." Journal of Labor Economics, Vol. 1, No. 3 (July), pp. 246-63.

1988. "Incentives and Performance." In Burton Weisbrod, ed., The Nonprofit Economy, pp. 43-58. Cam- 
bridge: Harvard University Press.

1989. "Rewarding Performance That is Hard to Measure: The Private Nonprofit Sector." Science, Vol. 244, pp. 541-46.
Werner, Steve, and Gretchen Gemeinhardt. 1995. "Nonprofit Organizations: What Factors Determine Pay Levels?” Compensation and Benefits Review, Vol. 27, No. 5, pp. 53-60. 